\title{
Interannual variability of summer surface mass balance and surface melting in the Amundsen sector, West Antarctica
}

\author{
Marion Donat-Magnin ${ }^{1}$, Nicolas C. Jourdain ${ }^{1}$, Hubert Gallée ${ }^{1}$, Charles Amory ${ }^{3}$, Christoph Kittel ${ }^{3}$, Xavier Fettweis ${ }^{3}$, \\ Jonathan D. Wille ${ }^{1}$, Vincent Favier ${ }^{1}$, Amine Drira ${ }^{1}$, and Cécile Agosta ${ }^{2}$ \\ ${ }^{1}$ Université Grenoble Alpes/CNRS/IRD/G-INP, IGE, 38000, Grenoble, France \\ ${ }^{2}$ Laboratoire des Sciences du Climat et de l'Environnement, IPSL/CEA-CNRS-UVSQ UMR 8212, CEA Saclay, \\ 91190, Gif-sur-Yvette, France \\ ${ }^{3}$ F.R.S.-FNRS, Laboratory of Climatology, Department of Geography, University of Liège, 4000 Liège, Belgium
}

Correspondence: Marion Donat-Magnin (marion.donatmagnin@gmail.com)

Received: 14 May 2019 - Discussion started: 24 May 2019

Revised: 29 November 2019 - Accepted: 12 December 2019 - Published: 27 January 2020

\begin{abstract}
Understanding the interannual variability of surface mass balance (SMB) and surface melting in Antarctica is key to quantify the signal-to-noise ratio in climate trends, identify opportunities for multi-year climate predictions and assess the ability of climate models to respond to climate variability. Here we simulate summer SMB and surface melting from 1979 to 2017 using the Regional Atmosphere Model (MAR) at $10 \mathrm{~km}$ resolution over the drainage basins of the Amundsen Sea glaciers in West Antarctica. Our simulations reproduce the mean present-day climate in terms of near-surface temperature (mean overestimation of $0.10^{\circ} \mathrm{C}$ ), near-surface wind speed (mean underestimation of $0.42 \mathrm{~m} \mathrm{~s}^{-1}$ ), and SMB (relative bias $<20 \%$ over Thwaites glacier). The simulated interannual variability of SMB and melting is also close to observation-based estimates.

For all the Amundsen glacial drainage basins, the interannual variability of summer SMB and surface melting is driven by two distinct mechanisms: high summer SMB tends to occur when the Amundsen Sea Low (ASL) is shifted southward and westward, while high summer melt rates tend to occur when ASL is shallower (i.e. anticyclonic anomaly). Both mechanisms create a northerly flow anomaly that increases moisture convergence and cloud cover over the Amundsen Sea and therefore favors snowfall and downward longwave radiation over the ice sheet. The part of interannual summer SMB variance explained by the ASL longitudinal migrations increases westward and reaches $40 \%$ for Getz. Interannual variation in the ASL relative central pressure is the largest driver of melt rate variability, with $11 \%$ to $21 \%$ of
\end{abstract}

explained variance (increasing westward). While high summer SMB and melt rates are both favored by positive phases of El Niño-Southern Oscillation (ENSO), the Southern Oscillation Index (SOI) only explains $5 \%$ to $16 \%$ of SMB or melt rate interannual variance in our simulations, with moderate statistical significance. However, the part explained by SOI in the previous austral winter is greater, suggesting that at least a part of the ENSO-SMB and ENSO-melt relationships in summer is inherited from the previous austral winter. Possible mechanisms involve sea ice advection from the Ross Sea and intrusions of circumpolar deep water combined with melt-induced ocean overturning circulation in ice shelf cavities. Finally, we do not find any correlation with the Southern Annular Mode (SAM) in summer.

\section{Introduction}

From 1992 to 2017, the Antarctic continent has contributed $7.6 \pm 3.9 \mathrm{~mm}$ to the global mean sea level (Shepherd et al., 2018), and this contribution may increase over the next century (Ritz et al., 2015; DeConto and Pollard, 2016; Edwards et al., 2019). The recent mass loss from the Antarctic ice sheet is dominated by increased ice discharge into the ocean (Shepherd et al., 2018), but both surface mass balance (SMB) and ice discharge may significantly affect the Antarctic contribution to future sea level rise (Asay-Davis et al., 2017; Favier et al., 2017; Pattyn et al., 2018). Despite recent improvements of ice sheet models motivated by newly available 
satellite products over the last 10-20 years, large uncertainties remain in both the SMB and ice dynamics projections, hampering our ability to accurately predict future sea level rise (Favier et al., 2017; Shepherd and Nowicki, 2017).

The largest ice discharge changes in Antarctica are observed in the Amundsen sector with an increase of $77 \%$ over the last decades (Mouginot et al., 2014). Current changes in the dynamics of glaciers flowing into the Amundsen Sea are dominated by ocean warming rather than changes in surface conditions over the ice sheet (Thoma et al., 2008; Pritchard et al., 2012; Turner et al., 2017; Jenkins et al., 2016, 2018). Increased oceanic melting can trigger marine ice sheet instability, leading to increased ice discharge, thinning ice, and retreating grounding lines (Weertman, 1974; Schoof, 2007; Favier et al., 2014; Joughin et al., 2014). In parallel, increased surface air temperature can lead to surface melting, subsequent hydrofracturing and possibly major thinning and retreat of outlet glaciers after the collapse of ice shelves (DeConto and Pollard, 2016). Surface melting, leading to meltwater ponding, drainage into crevasses and hydrofracturing, is thought to be the main cause of the Larsen ice shelf collapse over the last decades in the Antarctic Peninsula (van den Broeke, 2005; Scambos et al., 2009; Vaughan et al., 2003). While surface melting is currently limited to relatively rare events over the Amundsen Sea ice shelves (Nicolas and Bromwich, 2010; Trusel et al., 2012) and underlying reasons for melt pond formation versus active surface drainage network remain unclear (Bell et al., 2018), the rapid surface air warming observed (Steig et al., 2009; Bromwich et al., 2013) and projected (Bracegirdle et al., 2008) in this region suggests that surface melting could increase in the future. Our study focuses on the two atmospheric-related aspects that can significantly affect the contribution of the Amundsen Sea sector to sea level rise, i.e., snowfall accumulation that is expected to increase in a warmer climate and therefore to reduce the mean sea level and surface melting that could potentially induce more ice discharge and therefore increase the mean sea level.

Understanding the interannual variability of SMB and surface melting is key to (i) quantify the signal-to-noise ratio in climate trends, (ii) identify opportunities for seasonal predictions and (iii) assess the capacity of climate models to respond to global climate variability. Furthermore, years with particularly strong surface (or oceanic) melting could trigger irreversible grounding line retreat without the need for a long-term climate trend. Interannual variability in the Amundsen Sea region is usually described in terms of connections with the El Niño-Southern Oscillation (ENSO), the Southern Annular Mode (SAM) and the Amundsen Sea Low (ASL). Our study revisits these connections through dedicated regional simulations based on the MAR model (Fettweis et al., 2017; Agosta et al., 2019). Hereafter, we start by reviewing recent literature on these climate connections.

The El Niño-Southern Oscillation (ENSO; Philander et al., 1989) is the leading mode of ocean and atmosphere vari- ability in the tropical Pacific. It is the strongest climate fluctuation at the interannual timescale and can bring seasonal to multi-year climate predictability (e.g. Izumo et al., 2010). Global climate models predict an increasing number of extreme El Niño events in the future, with large global impacts (Cai et al., 2014, 2017). Interannual and decadal variability in the tropical Pacific affects air temperature (Ding et al., 2011), snowfall (Bromwich et al., 2000; Cullather et al., 1996; Genthon and Cosme, 2003), sea ice extent (Pope et al., 2017; Raphael and Hobbs, 2014) and upwelling of circumpolar deep water favoring ice shelf basal melting (Dutrieux et al., 2014; Steig et al., 2012; Thoma et al., 2008) in West Antarctica. Recent studies found concurrences between El Niño events and summer surface melting over West Antarctic ice shelves (Deb et al., 2018; Nicolas et al., 2017; Scott et al., 2019). These connections are generally explained in terms of Rossby wave trains excited by tropical convection during El Niño events and inducing an anticyclonic anomaly over the Amundsen Sea (Ding et al., 2011). Paolo et al. (2018) reported a positive correlation between ENSO and the satellitebased ice shelf surface height in the Amundsen Sea over 1994-2017. Based on a detailed study of the extreme El Niño-La Niña sequence from 1997 to 1999, these authors suggested that El Niño events could increase snow accumulation but also increase ocean melting even more, thus leading to an overall ice shelf mass loss. The impact of ENSO was found to be stronger for the Dotson ice shelf and eastward and weaker for Pine Island and Thwaites (Paolo et al., 2018). However, the aforementioned studies were based on the analysis of a few recent ENSO events and did not account for the highly variable properties of ENSO over multi-decadal periods (e.g. Deser et al., 2012; Newman et al., 2011).

The Southern Annular Mode (SAM; Hartmann and Lo, 1998; Limpasuvan and Hartmann, 1999; Thompson and Wallace, 2000) is the dominant mode of atmospheric variability in the Southern Hemisphere and corresponds to a variation in the strength and position of the circumpolar westerlies. Over the last 3 to 5 decades, the SAM has exhibited a positive trend; i.e., westerly winds have been strengthening and shifting poleward (Chen and Held, 2007; Jones et al., 2016; Marshall, 2003). Medley and Thomas (2019) found similar patterns for the SAM trends and the reconstructed snow accumulation trend over 1801-2000. By contrast, the temperatures above the melting point over the Amundsen ice shelves were found to be largely insensitive to the polarity of the SAM (Deb et al., 2018). The SAM phase has also been suggested to influence the ENSO teleconnection to the south Pacific: in-phase ENSO and SAM events (i.e. El Niño-SAMor La Niña-SAM+) favor anomalous transient eddy momentum fluxes in the Pacific that make the ENSO teleconnection to the South Pacific stronger than average (Fogt et al., 2011).

The Amundsen Sea Low (ASL; Raphael et al., 2016; Turner et al., 2013a) is a dynamic low-pressure system located in the Pacific sector of the Southern Ocean and moving across the Ross, Amundsen and Bellingshausen seas. The 
ASL is important regionally and variations in its central pressure and position respectively reflect the second and third leading modes of the Southern Hemisphere climate (Scott et al., 2019, their Fig. 3). A westward shift of the ASL induces northerly flow anomalies over the Amundsen Sea, leading to warmer conditions and increased moisture transport over the ice sheet (Hosking et al., 2013, 2016; Thomas et al., 2015; Raphael et al., 2016; Fyke et al., 2017). Variations in the ASL central pressure also largely impact the West Antarctic climate: anticyclonic anomalies near $120^{\circ} \mathrm{W}$ lead to marine air intrusion over the ice sheet, thereby increasing cloud cover, longwave downward radiations and surface air temperature over the West Antarctic Ice Sheet (WAIS; Scott et al., 2019). While a deepening of the ASL is predicted for the twenty-first century in response to greenhouse gas emissions, its high regional variability makes future changes of the ASL difficult to predict (Hosking et al., 2016; Turner et al., 2009).

Importantly, ENSO and SAM are not independent of each other, and both modes of climate variability impact the ASL (Fogt and Wovrosh, 2015). SAM influences the ASL central pressure since it affects the mean sea level pressure over Antarctica (Turner et al., 2013a). The second and third leading modes of variability in the South Pacific have been suggested to be affected by Rossby wave trains induced by tropical convection anomalies (Mo and Higgins, 1998). In terms of ASL, it corresponds to a migration further west (east) during the La Niña (El Niño), but the difference has a low statistical significance (Turner et al., 2013b). Scott et al. (2019) recently reported that $\mathrm{El}$ Niño conditions favored blocking in the Amundsen Sea as well as a negative SAM phase, both leading to warm surface air anomalies in West Antarctica.

In this study we revisit the influence of ENSO, SAM and ASL on summer SMB and melting over the drainage basins of the Amundsen sector in West Antarctica for the 19792017 period. While the summer focus on melt rates is obvious, SMB in DJF (i.e. December-January-February) only represents $15 \%$ of the annual SMB. It is nonetheless interesting to analyze the similarities and differences in what drives SMB and melting, and the modes of variability and their teleconnections to the Amundsen Sea region both have strong seasonal characteristics, so that each season needs to be considered separately. To do so, we simulate the surface conditions of the Amundsen Sea region over 19792017 using the polar-adapted Regional Atmosphere Model (MAR) forced by the ERA-Interim reanalysis. Section 2 describes the methodology followed in the study and presents the model and observations used for comparison. The model results are analyzed and evaluated against observations in Sect. 3. After evaluating the model skills (Sect. 3.1), we analyze and discuss our results on the potential impact of large-scale climate variabilities on the SMB and melting in Sects. 3.2 and 4. The conclusions are provided in Sect. 5.

\section{Materials and method}

\subsection{Model}

To estimate SMB and surface melt over the Amundsen sector we use the Regional Atmosphere Model (MAR; Gallée and Schayes, 1994) and specifically version 3.9.3 (http://mar. cnrs.fr, last access: 25 September 2019). The model solves the primitive equations under the hydrostatic approximation. It solves conservation equations for specific humidity, cloud droplets, raindrops, cloud ice crystals and snow particles (Gallée, 1995; Gallée and Gorodetskaya, 2010). MAR represents coupled interactions between the atmospheric surface boundary layer and the snowpack using the Soil Ice Snow Vegetation Atmosphere Transfer (SISVAT) originally developed by De Ridder and Gallée (1998). The snow-ice part of SISVAT includes submodules for surface albedo, meltwater percolation, and refreezing and snow metamorphism based on an early version of the CROCUS model (Brun et al., 1992). MAR has been largely evaluated in polar regions (e.g. Amory et al., 2015; Gallée et al., 2015; Lang et al., 2015; Fettweis et al., 2017; Kittel et al., 2018; Agosta et al., 2019; Datta et al., 2019).

Our domain includes the drainage basins of the Amundsen Sea Embayment glaciers and a large part of the Amundsen Sea until $65^{\circ} \mathrm{S}$ using oblique stereographic projection (EPSG: 3031). It covers an area of $2800 \mathrm{~km} \times 2400 \mathrm{~km}$ at $10 \mathrm{~km}$ horizontal resolution (Fig. 1) and 24 vertical sigma levels located from approximately 1 to $15500 \mathrm{~m}$ above the ground. We use 30 snow layers, resolving the first $20 \mathrm{~m}$ of the snowpack, with a fine vertical resolution at the surface $(1 \mathrm{~mm})$ increasing with depth; snow layer thickness varies dynamically depending on the physical properties of overlying snow layer properties. If neighboring layers have similar properties, then layers are associated together. The radiative scheme and cloud properties are the same as in Datta et al. (2019) and the surface scheme including snow density and roughness is the same as in Agosta et al. (2019). The model is forced, over the period 1979-2017, by ERAInterim reanalysis (Dee et al., 2011), which performs well over Antarctica (Bromwich et al., 2011; Huai et al., 2019), at 6-hourly temporal resolution and relaxed over $\sim 50 \mathrm{~km}$ laterally (pressure, wind, temperature, specific humidity; the relaxation zone is shown in Fig. 1), at the top (i.e. above $10 \mathrm{~km}$ ) of the troposphere (temperature, wind) and at the surface (sea ice concentration, sea surface temperature). The Bedmap2 surface elevation dataset is used for the ice sheet topography (Fretwell et al., 2013). The snowpack density and temperature are initialized from the pan-Antarctic simulation from Agosta et al. (2019). Drifting snow is relatively infrequent in the Amundsen region (Lenaerts et al., 2012) so that the drifting snow module has been switched off in our configuration, similar to in Agosta et al. (2019).

In Sect. 3.2 we provide the SMB constituents averaged over individual drainage basins. 


\subsection{Antarctic surface observations}

We make use of meteorological data from the SCAR database including observations from the Italian Antarctic Research Program (http://www.climantartide.it, last access: 25 September 2019), the Antarctic Meteorological Research Center (AMRC program) (http://amrc.ssec.wisc.edu/, last access: 25 September 2019) and the Australian Antarctic automatic weather station (AWS) dataset (http://aws.acecrc.org. au/, last access: 25 September 2019). Among the 243 AWSs available over Antarctica since 1980, we selected the 41 stations (see Table S1 in the Supplement for station names) located no more than $15 \mathrm{~km}$ from the closest continental MAR grid point (even if the domain resolution is $10 \mathrm{~km}$, stations over islands or capes that are not resolved can be located farther than $15 \mathrm{~km}$ from the closest continental MAR grid point). For each location, modeled values (surface pressure, near-surface temperature and near-surface wind speed) are computed as the average-distance-weighted value of the four nearest continental grid points. A second selection criterion is also applied in order to reduce comparison errors due to the difference between the model surface elevation and the actual AWS elevation: we only retain observations with an elevation difference lower than $250 \mathrm{~m}$. This two-stage selection leaves 41 suitable AWSs in our domain (Fig. 1).

To evaluate the simulated SMB, we use airborne-radar data from Medley et al. $(2013,2014)$ covering the period 1980-2011. These data were collected through NASA's Operation IceBridge campaign over the Thwaites and Pine Island basins. They are based on the CReSIS radar (Center for Remote Sensing of Ice Sheets), which is an ultra-wideband radar system able to measure the stratigraphy of the upper $20-30 \mathrm{~m}$ of the snowpack with a few centimeters in vertical resolution. Airborne-radar data were verified with 190 firn core accumulation records. To evaluate the SMB regional pattern at a broader scale, we also compared the simulated SMB with the observations gathered in the GLACIOCLIMSAMBA dataset thoroughly described by Favier et al. (2013) and updated by Wang et al. (2016) that are covered by our domain. Similar to Kittel et al. (2018) and Agosta et al. (2019), we selected the observations for which the measurement period extends from 1950 to 2018. Observations before 1979 (i.e., the beginning of our study period) were compared to the average SMB simulated by MAR provided they cover a period of at least 5 years, while observations after 1979 were compared to the SMB modeled by MAR for the observation period. We then compared the modeled SMB computed by using a four-nearest inverse-distance-weighted method for each of the 124 selected SMB observations.

To evaluate simulated surface melt, we use satellitederived estimates of surface meltwater production over 1999-2009 from Trusel et al. (2013), provided at $4.45 \mathrm{~km}$ resolution, and based on the QuickSCAT backscatter and calibrated with in situ observations. We also use data from Nicolas et al. (2017), who provide the number of melt days at $25 \mathrm{~km}$ resolution over Antarctica. This product is based on passive microwave observations from the Scanning Microwave Multichannel Radiometer (SMMR), the Special Sensor Microwave/Imager (SSM/I) and the Special Sensor Microwave Imager/Sounder (SSMIS) spaceborne sensors and covers the 1978-2017 period. For a given grid cell and a given day, melt is assumed to occur as soon as one of the two daily observations of brightness temperature exceeds a threshold value. As the identification of melt days may be sensitive to the algorithm, we also use the dataset from Picard et al. (2007), extended to 2018 (http:// pp.ige-grenoble.fr/pageperso/picardgh/melting/, last access: 25 September 2019). This dataset is also based on SMMR and SSM/I but uses the algorithms from Torinesi et al. (2003) and Picard and Fily (2006) to retrieve melt days. It is provided as daily melt status at $25 \mathrm{~km}$ resolution over the Antarctic continent from 1979 to 2018.

\subsection{Climate indices}

To describe the ENSO, we use the Southern Oscillation Index (SOI) from the Global Climate Observing System (GCOS) Working Group on Surface Pressure (Ropelewski and Jones, 1987; https://www.esrl.noaa.gov/psd/gcos_wgsp/ Timeseries/SOI/, last access: 25 September 2019). The SOI corresponds to the normalized pressure difference between Tahiti and Darwin based on observations. The Rossby wave trains connecting the equatorial Pacific to Antarctica are expected to develop within a few weeks in response to ENSO anomalies (e.g. Hoskins and Karoly, 1981; Mo and Higgins, 1998; Peters and Vargin, 2015), so we first use the synchronous (DJF) SOI in Sect. 3. The lagged relationship to ENSO is discussed in Sect. 4, where we use other 3-month averages of SOI such as JJA (June-July-August). SOI is preferred to NINO3.4 because it gives slightly stronger correlations with the variability in the Amundsen Sea region (as also found by Scott et al., 2019; Holland et al., 2019), but very similar results were obtained using NINO3.4 (not shown).

We use the SAM index from NOAA/CPC (https: //stateoftheocean.osmc.noaa.gov/atm/sam.php, last access: 25 September 2019) to describe the primary mode of atmospheric variability in the Southern Ocean (e.g., Marshall, 2003). The SAM index is calculated as the difference of mean zonal pressure between the latitudes of 40 and $65^{\circ} \mathrm{S}$ based on NCEP/NCAR reanalysis which produces a SAM that is consistent with other reanalyses after 1979 (Gerber and Martineau, 2018). In the negative (positive) phase, the mean sea level pressure anomaly between the Antarctic and midlatitudes is positive (negative) and leads to a weaker (stronger) polar jet. Thus, positive (negative) values of the SAM index correspond to westerlies that are stronger (weaker) than average over the middle to high latitudes (50$70^{\circ} \mathrm{S}$ ) and weaker (stronger) westerlies in the midlatitudes $\left(30-50^{\circ} \mathrm{S}\right)$. 
We use two other indices to describe the evolution of the migration and intensity variations in the Amundsen Sea Low (ASL). The datasets are provided by the British Antarctic Survey (https://legacy.bas.ac.uk/ data/abs1/ASL-index-Version2-Seasonal-ERA-Interim Hosking2016.txt, last access: 25 September 2019) and calculated from the ERA-Interim reanalysis. To describe the migration, we use the longitudinal position of the ASL defined as the position of the minimum pressure within the box $80-60^{\circ} \mathrm{S}, 170-298^{\circ} \mathrm{E}$ (Hosking et al., 2016), defined in degrees east. A decrease in the longitudinal position index hence corresponds to a westward shift of the ASL. To describe the intensity of the ASL, we use the relative central pressure of the ASL calculated as the minimum pressure in the aforementioned box minus the average pressure over that box (Hosking et al., 2016). A more intense ASL (deeper depression) is therefore represented by a lower index.

The SAM and ASL indices are defined regionally, and we do not expect any lag with summer SMB, so these indices are therefore calculated as DJF averages. All the correlations are calculated using detrended time series.

The correlations between these four indices are indicated in Table 1. A significant anticorrelation is obtained between the SAM index and ENSO (i.e. - SOI) as previously reported by Fogt et al. (2011). There is no significant relationship between the ASL longitudinal position and ENSO or SAM, as previously reported by Turner et al. (2013a). The relative central pressure also varies independently from SAM, ENSO and the ASL longitudinal position. Numerous previous studies used the absolute rather than relative central pressure to characterize the ASL, but this index is strongly correlated to the SAM index and cannot be considered independently (Table 1). As proposed by Hosking et al. (2013), the ASL relative central pressure (i.e. actual central pressure minus pressure over the AS sector) allows for a better understanding of West Antarctic climate as it removes the influence of large-scale variability such as ENSO and SAM.

\section{Results}

We first evaluate the simulations with regard to observations (Sect. 3.1). Then we analyze the interannual variations in SMB and melting (Sect. 3.2).

\subsection{Model evaluation}

We first evaluate the near-surface temperature and nearsurface wind speed in comparison to AWS data (Fig. 2).

Our MAR configuration reproduces the daily near-surface temperatures, with a mean bias of $0.10^{\circ} \mathrm{C}$ and a mean correlation of 0.93 for the whole year and 0.86 for summer months (Fig. 2a). The statistics per station show a root-mean-square error (RMSE) varying from 2.66 (10th percentile) to $4.15^{\circ} \mathrm{C}$

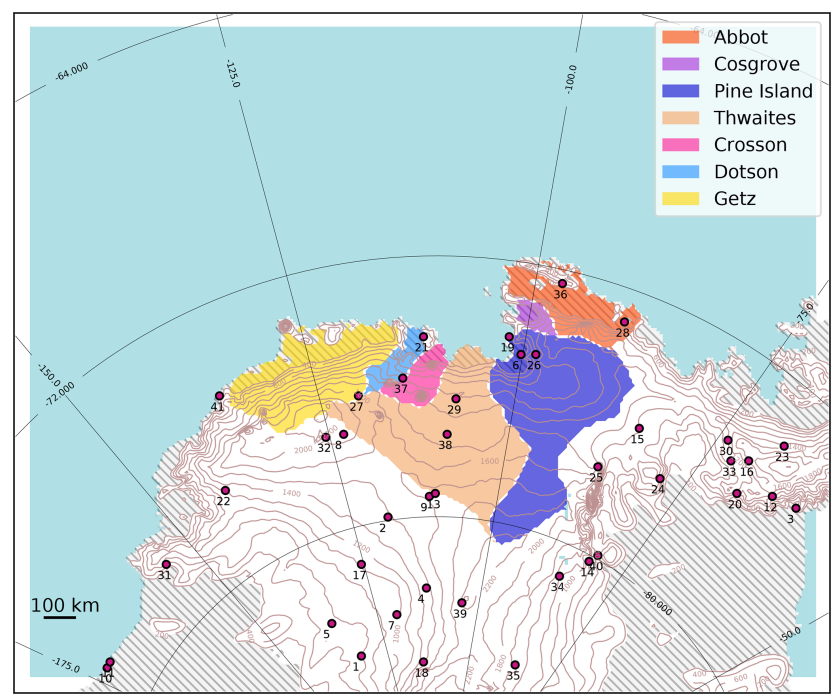

Figure 1. Simulation domain. The drainage basins (Rignot et al., 2019) under consideration in this paper are shaded in color and Automatic Weather Stations (AWSs) are indicated with red points. The hatched area represents ice shelves and contour lines the surface elevation (every $200 \mathrm{~m}$ ). Station names from 1 to 41: (1) Brianna, (2) Byrd, (3) Cape Adams, (4) Doug, (5) Elizabeth, (6) Evans Knoll, (7) Harry, (8) Janet , (9) Kominko-Slade, (10) Martha II, (11) Martha I, (12) Mount McKibben, (13) Noel, (14) Patriot Hills, (15) Siple Dome, (16) Ski Hi, (17) Swithinbank, (18) Theresa, (19) Backer Island, (20) Bean Peaks, (21) Bear Peninsula, (22) Clarke Mountains, (23) Gomez Nunatak, (24) Haag Nunatak, (25) Howard Nunatak, (26) Inman Nunatak, (27) Kohler Glacier, (28) Lepley Nunatak, (29) Lower Thwaites Glacier, (30) Lyon Nunatak, (31) Mount Paterson, (32) Mount Sidley, (33) Mount Suggs, (34) Patriot Hills, (35) Steward Hills, (36) Thurston Island, (37) Toney Mountain, (38) Up Thwaites Glacier, (39) Whitmore Mountains, (40) Wilson Nunatak, (41) Russkaya. The relaxation zone is shown in white $(\sim 50 \mathrm{~km})$.

(90th percentile) and a mean bias varying from -1.97 to $1.31^{\circ} \mathrm{C}$ for the whole year (see Supplement for more details).

The model tends to overestimate the lowest observed wind and underestimate the highest observed wind speeds (regressions in Fig. 2b). The model agreement with observations is nonetheless good on average, with a mean underestimation of $0.42 \mathrm{~m} \mathrm{~s}^{-1}$. The statistics per station show a RMSE varying from 1.73 to $3.69 \mathrm{~m} \mathrm{~s}^{-1}$ and a mean bias varying from -3.08 to $0.85 \mathrm{~m} \mathrm{~s}^{-1}$ for the whole year. The variance of the wind speed simulated by MAR is lower than observed. Less satisfactory results are generally found for the stations located on an island. This can be explained by the resolution of $10 \mathrm{~km}$, which is still too coarse to resolve small topographic features. For both near-surface temperature and wind speed, the statistics for the summer period (DJF) are very similar to the statistics for the whole year. Our results show very similar model skills compared to other simulations in the same region (Deb et al., 2018; Lenaerts et al., 2017) or at coarser resolution over the whole ice sheet (Agosta et al., 2019). 
Table 1. Correlation between climate indices (-SOI, SAM, ASL longitudinal position, ASL relative central pressure, ASL actual central pressure) in austral summer (DJF). Values in brackets represent the percentage of significance.

\begin{tabular}{|c|c|c|c|c|c|}
\hline $\begin{array}{l}\text { Statistical } \\
\text { correlation }(R)\end{array}$ & $-\mathrm{SOI}$ & SAM & $\begin{array}{l}\text { ASL longitudinal } \\
\left.\text { position ( }{ }^{\circ} \text { east }\right)\end{array}$ & $\begin{array}{r}\text { ASL relative } \\
\text { central } \\
\text { pressure }(\mathrm{hPa})\end{array}$ & $\begin{array}{r}\text { ASL actual } \\
\text { central } \\
\text { pressure }(\mathrm{hPa})\end{array}$ \\
\hline$-\mathrm{SOI}$ & & $-0.45(99 \%)$ & $-0.22(82 \%)$ & $0.00(1 \%)$ & $0.40(99 \%)$ \\
\hline SAM & & & $0.18(73 \%)$ & $-0.25(88 \%)$ & $-0.88(99 \%)$ \\
\hline $\begin{array}{l}\text { ASL longitudinal } \\
\left.\text { position ( }{ }^{\circ} \text { east }\right)\end{array}$ & & & & $-0.23(84 \%)$ & $-0.15(63 \%)$ \\
\hline
\end{tabular}
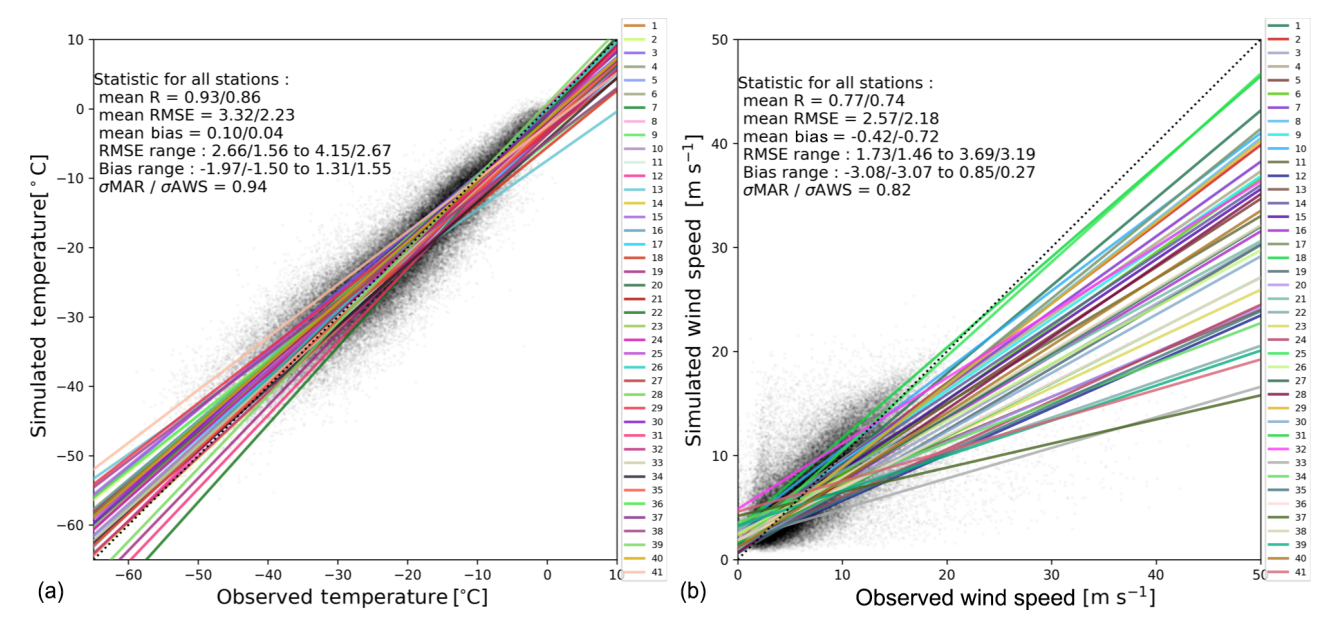

Figure 2. Scatter plots of observed vs. simulated daily near-surface temperature (a) and daily near-surface wind speed (b) for the selected AWSs (see corresponding locations and names in Fig. 1). The statistics, including RMSE, correlation $(R)$, bias, and standard deviations $(\sigma)$, are calculated for individual stations and provided as multi-station mean over the whole year and over the summer months (DJF). The range of RMSE and biases across individual stations is also indicated with the 10th percentile and the 90th percentile of all RMSE values. The lines represent least-mean-square linear fit between simulated data and observations. The complete statistical analyses for individual AWSs are provided in the Supplement (Tables S1-S2).

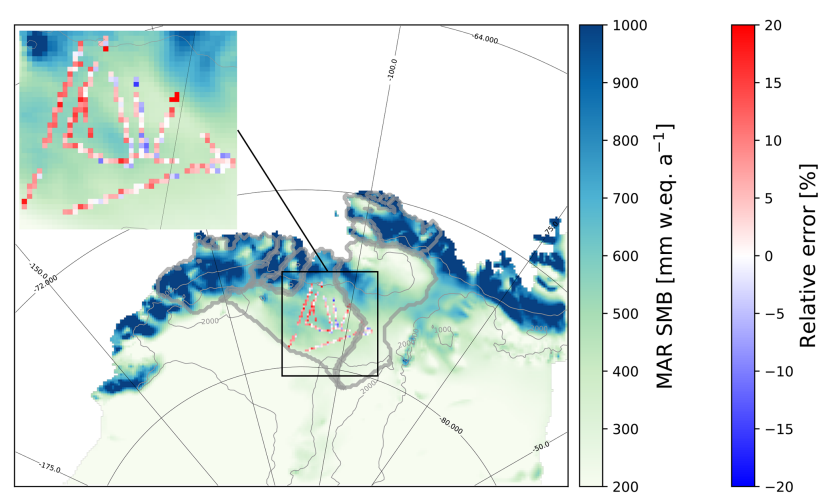

Figure 3. Annual mean (1979-2017) simulated SMB (blue-green scale) and relative error of the simulated SMB compared to the airborne-radar data from Medley et al. (2013, 2014) (blue-red color bar). Grey contours indicate the surface height (every $1000 \mathrm{~m}$ ). The drainage basins under consideration are the same as in Fig. 1 (large grey contours here).
We now assess the simulated SMB compared to the SMB from Medley et al. $(2013,2014)$ derived from airborne radar over the period 1980-2011. The simulated SMB is well captured by MAR with a mean relative overestimation of approximately $10 \%$ over the Thwaites basin and local errors smaller than $20 \%$ at all locations (Fig. 3). The interannual variability is also well simulated by MAR with a correlation of 0.90 (Fig. 4). In order to have a broad overview of the SMB evaluation, we also compared the simulated SMB with the GLACIOCLIM-SAMBA dataset (Favier et al., 2013) over the Ross and Siple Coast sector (See Fig. S1 in the Supplement). The bias of simulated SMB compared to observation SMB is less than $10 \mathrm{~mm}$ w.e. $\mathrm{a}^{-1}$ and local bias can reach $30 \mathrm{~mm}$ w.e. $\mathrm{a}^{-1}$. However, the relative bias between the GLACIOCLIM-SAMBA dataset and simulated SMB is more pronounced with only $44 \%$ of GLACIOCLIM-SAMBA sites showing a relative error with simulated SMB lower than $20 \%$. All SMB components are shown in Table 2.

The areas of highest surface melt $\left(>100 \mathrm{~mm} \mathrm{w.e.}^{-1}\right)$ are located near the coast and particularly over Abbot, Cos- 


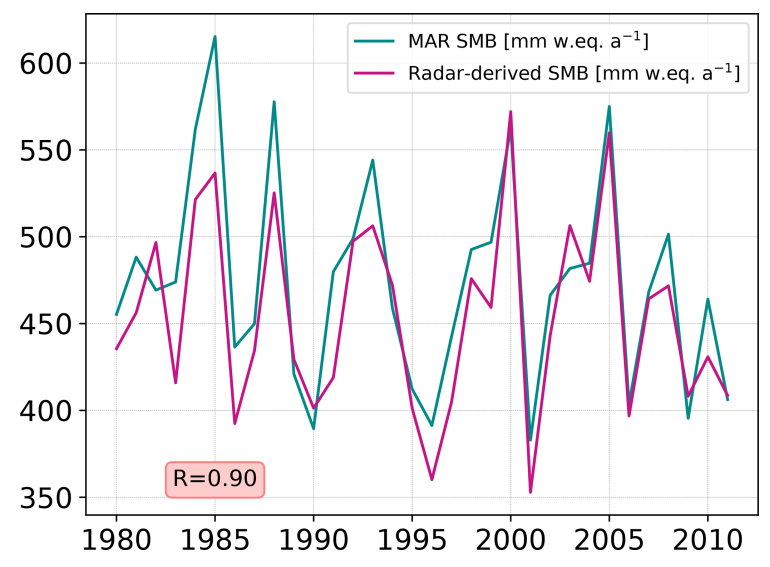

Figure 4. Time series of the annual mean (January to December) simulated and radar-derived SMB from 1980 to 2011 over the Thwaites basins.

grove and the eastern part of Pine Island ice shelf, while more extreme values $\left(>200 \mathrm{~mm}\right.$ w.e. $\mathrm{a}^{-1}$ ) are found near the peninsula in both simulated and observed datasets (Fig. 5). Even if the simulated and observed patterns are similar, the simulated surface melt is a factor of 2 lower than observations locally (e.g. over Abbot ice shelf and the peninsula). While the interannual melt rate variability is well reproduced with a correlation of 0.80 , the surface melt rate simulated by MAR is underestimated by $18 \%$ on average compared to QuickSCAT estimates (Fig. 6a). Surface melt rate over Pine Island basins is well simulated by MAR (Fig. 6b) with $R$ equal to 0.80 compared to drainage basins with low surface melt (i.e. Crosson, Dotson) where $R$ is equal to 0.14 and 0.24 , respectively. This melt underestimation, particularly pronounced over drainage basins with low surface melt rate, could be explained by the slight overestimation of the snowfall accumulation (10\%-20\%), as the presence of a fresh snow layer of high albedo overlying snow or ice layers of lower albedo likely reduces melt. MAR surface melt presents a slight overestimation over Getz ice shelf (Fig. 5) possibly explained by wind advection, foehn effect or even snow metamorphism simulated by MAR. Further work is needed to understand such local biases. MAR is fully driven by low-resolution ERA-Interim sea ice cover and temperature; therefore possible underestimation of the presence of polynyas can also play a role in the melt biases.

We also compare the number of melt days to the satellite products from Nicolas et al. (2017) and Picard et al. (2007). To avoid no-melt-day areas in the time series computation, we use the area where the annual number of melt days for each dataset is more than 3 melt days per year, which corresponds approximately to the ice shelf zone. As with the amount of surface melt, the number of melt days over the domain is underestimated by MAR (Fig. 7). The amplitude of the underestimation is not very sensitive to the melt rate threshold used to define a melt day in MAR. A threshold of
$1 \mathrm{~mm}$ w.e. $\mathrm{d}^{-1}$ (as in Datta et al., 2019) gives a mean underestimation of $4.8 \mathrm{~d}$ per year compared to observation from Nicolas et al. (2017), while a threshold of $3 \mathrm{~mm}$ w.e. $\mathrm{d}^{-1}$ (as in Deb et al., 2018; Lenaerts et al., 2017) gives a mean underestimation of $4.9 \mathrm{~d}$ per year. This underestimation is less pronounced $(0.8$ to $0.9 \mathrm{~d}$ per year depending on the threshold) when using Picard et al. (2007) as a reference. The interannual variability in the number of melt days is reproduced with correlations of 0.69 and 0.43 to the two satellite products (Fig. 7). Previous study on the Antarctic peninsula also found that MAR melt occurrence is comparable to satellite products, but slightly underestimated over the western coast of the Peninsula (Datta et al., 2019).

Overall, MAR simulates the interannual variability of the Amundsen sector well, and we are now going to use these simulations to investigate the drivers of interannual variability of SMB and surface melting.

\subsection{Drivers of summer interannual variability}

In this subsection, we first investigate the large-scale conditions leading to interannual anomalies in summer SMB or surface melting. For sake of clarity, we only consider the Pine Island and Thwaites basins (together) as a first approach. To identify large-scale conditions leading to high (low) SMB, we calculate composites defined as the average of summers presenting a SMB greater than the 85th (lower than the 15th) interannual percentile, and we proceed similarly for surface melt composites. We choose the 85 th and 15 th percentiles to optimize the signal-to-noise ratio.

Sea surface pressure composites show that distinct mechanisms affect the interannual variability of summer SMB and surface melting (Fig. 8). Summers with high SMB are on average characterized by a far westward (by $\sim 30^{\circ}$ ) and southward (by $3-4^{\circ}$ ) migration of the ASL center, while the reverse migration is found for summers with low SMB, although with a smaller displacement $\left(\sim 15^{\circ}\right.$ eastward $)$. In contrast, years with high surface melt rates are characterized by a much smaller ASL migration, and no migration is found for years with low surface melt rates, but the pressure gradients differ between the high and low composites. Therefore, we hereafter consider the variability of SMB and surface melting separately.

To further characterize the tropospheric circulation associated with years of low or high summer SMB, we plot composites of both the $500 \mathrm{hPa}$ geopotential height (Fig. 9a, b) and the $500 \mathrm{hPa}$ geopotential height divided by the domainaveraged value for each season (Fig. 9c, d). The latter has the advantage of highlighting changes in regional gradients (related to the regional circulation) rather than largerscale changes in geopotential height. Both provide similar composites, but the statistical significance is higher in Fig. 9c, d. On average, low-SMB summers are characterized by a northward and eastward ASL migration (shown through a dipole in the $500 \mathrm{hPa}$ normalized geopotential composite 


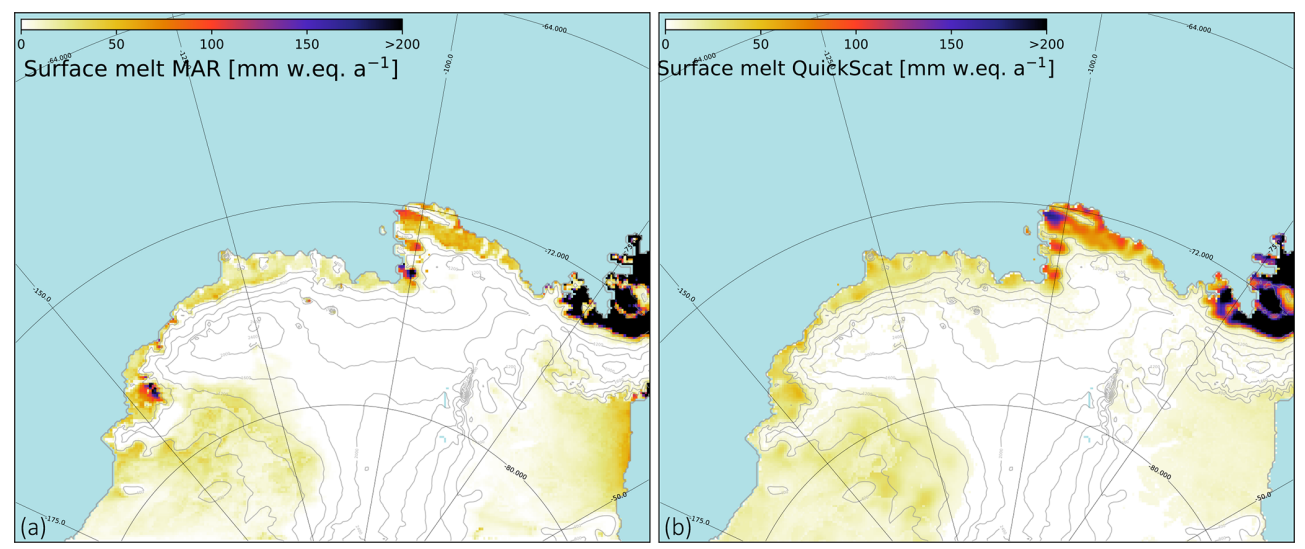

Figure 5. Annual surface melt rate (a) simulated by MAR over 1999-2009 and (b) derived from QuickSCAT satellite data over the same period (Trusel et al., 2013) and interpolated over the MAR grid.
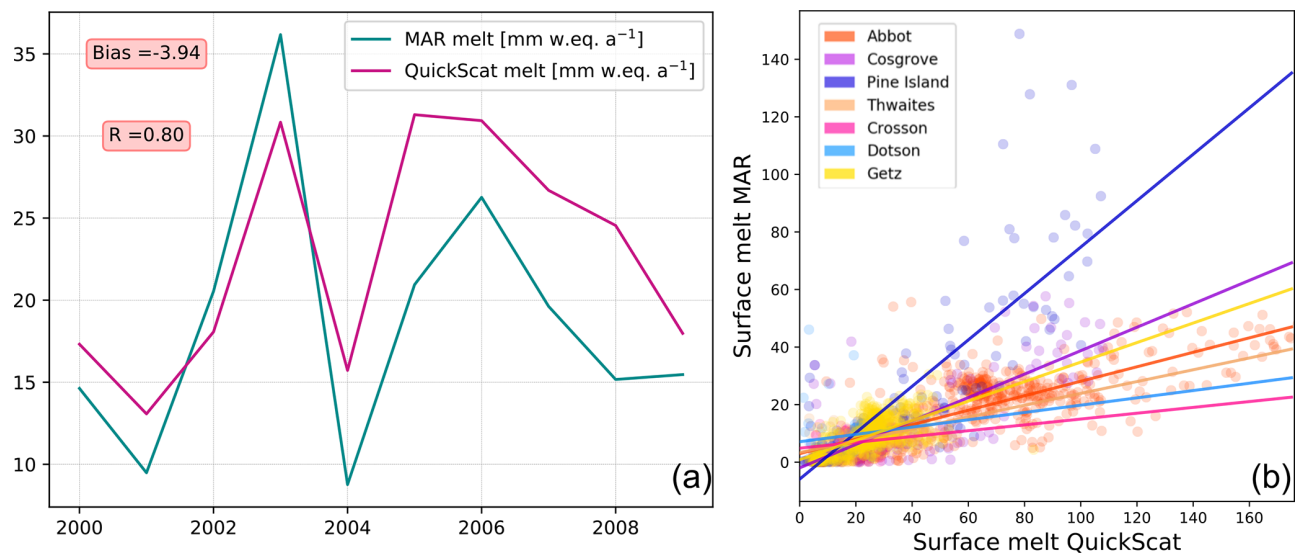

Figure 6. (a) Time series of surface melt rates in mean over the model domain derived from satellite data and simulated by MAR; years labeled on the $X$ axis refer to the second year of a given austral summer (e.g., summer 1999-2000 is labeled 2000). (b) Surface melt modeled

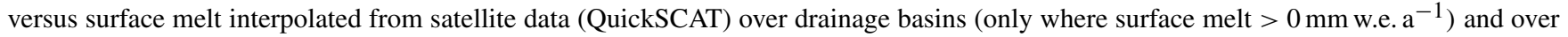
the period 1999-2009.

in Fig. 9a, c), which is associated with an offshore surface wind anomaly over the glaciers of the Amundsen Sea sector (Fig. 9e). Conversely, high-SMB summers are characterized by a southward and westward ASL migration (Fig. 9b, d), which is associated with an onshore surface wind anomaly over the glaciers of the Amundsen sector (Fig. 9f). The circulation anomalies typical of high-SMB summers favor the southward transport of precipitable water as indicated by the composites of integrated vapor transport (Fig. 10a, b). Increased moisture transport towards the Amundsen Sea Embayment leads to denser cloud cover (Fig. 10c, d) and increased SMB.

On average, high-melt summers are also associated with increased moisture transport towards the Amundsen Sea Embayment and conversely for low-melt summers (Fig. 11a, b), but the mechanism is somewhat different from the case of SMB. The ASL migration during high-melt summers is much smaller than for the high-SMB summers (Fig. 8b). As previously done for SMB, we plot composites of both the $500 \mathrm{hPa}$ geopotential height (Fig. 12a, b) and the $500 \mathrm{hPa}$ geopotential height divided by the domain-averaged value for each season (Fig. 12c, d), the latter better highlighting regional circulation changes (geopotential gradients). Summers with high surface melt rates show a significant increase in the $500 \mathrm{hPa}$ geopotential height over the Bellingshausen Sea (Fig. 12b), i.e. an anticyclonic anomaly, and small westward ASL migration as shown in the $500 \mathrm{hPa}$ normalized geopotential composite (Fig. 12d). This anomaly is against the ASL mean circulation and creates a northerly flow anomaly over the ice sheet in the Amundsen sector (Fig. 12e, f). This anticyclonic anomaly was described by Scott et al. (2019) in terms of enhanced blocking activity. As in Scott et al. (2019), we find that high-melt summers are associated with denser cloud cover (Fig. 11c, d) and increased downward longwave radiation (Fig. 11e, f), and therefore surface air warming, while the opposite occurs for low-melt 


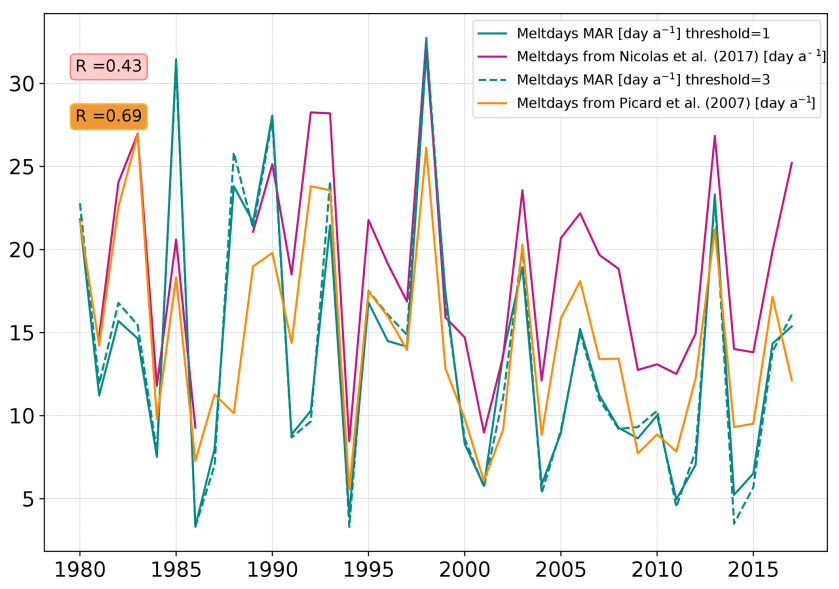

Figure 7. Time series of the number of melt days per summer (DJF) averaged over the part of the domain with more than 3 melt days per year on average (which approximately corresponds to the ice shelf zone), derived from two satellite products and simulated by MAR (defined using a melt rate threshold of either 1 or $3 \mathrm{~mm}$ w.e. $\mathrm{d}^{-1}$ ).

summers. Composites of sensible heat flux indicate that heat is lost by the snow surface to the atmosphere for high-melt summers, i.e. high melt summers are not caused by foehn events on average (Fig. S2).

Now that we have described the mechanisms in play for summers with high and low SMB or surface melt rates, we investigate the connections between the leading modes of climate variability (ENSO, SAM and ASL variability) and summer SMB and surface melting over the individual Amundsen drainage basins (shown in Fig. 1).

In line with the previous composite analysis for highand low-SMB composites, the SMB in all the drainage basins is anticorrelated to the ASL longitudinal position (Table 3, fourth column). This anticorrelation has little statistical significance for Abbot and Cosgrove, but for Dotson and Thwaites the ASL longitudinal position explains nearly $40 \%$ of the SMB interannual variance (explained variance given by square correlations). The ENSO-SMB relationship has moderate levels of statistical significance, with positive SMB correlations to - SOI for all basins but a part of SMB variance explained by ENSO that remains below $16 \%$ (Table 3, second column). - SOI and the ASL longitudinal location are not significantly connected together (Table 1); therefore their connection to SMB can be considered independent from each other. Finally, the SMB is significantly correlated to neither the ASL relative central pressure (Table 3, fifth row) nor the SAM index (Table 3, third column) for all the basins. To better describe interplays, we also calculate a multi-linear regression of SMB on the four indices (last column of Table 3). Accounting for several indices increases the explained SMB variance compared to a single index, indicating an interplay of the ASL and ENSO. Overall, $16 \%$ to $49 \%$ of the summer
SMB variance (increasing westward) can be explained by a linear combination of the climate indices.

We now investigate similar relationships, but with surface melt rates instead of SMB. By contrast to SMB, the surface melt connection to the ASL relative central pressure is stronger than its connection to the ASL longitudinal position (Table 4, fourth and fifth columns), which again highlights the two distinct mechanisms explaining high or low melt rates vs. high or low SMB. The part of the melt rate variance explained by the ASL relative central pressure increases westward, from $12 \%$ for Abbot to $21 \%$ for Getz. Even though the effect of the ASL central pressure dominates, there is still a moderate anticorrelation between melt rates and the ASL longitudinal position, suggesting that the mechanism explaining high and low SMB can explain a small part of the melt rate variance (less than $10 \%$ ). In a way similar to SMB, SOI explains less than $9 \%$ of the melt rate's variance, with moderate statistical significance (Table 4, second column), and as for summer SMB there is no significant relationship to the SAM. We have repeated the calculations considering the number of melt days, and we find very similar results in terms of correlations (Table 4, second line in each row). Relatively similar conclusions can be drawn from observational estimates of the number of melt days (values in italic in Table 4), except that satellite estimates indicate a stronger correlation to -SOI, even exceeding the correlation to the ASL central pressure in the case for most drainage basins (the variance explained by - SOI reaching $25 \%$ ). As the SAM index is significantly anticorrelated to ENSO (Table 1), the stronger melt-SOI correlation in the observational products goes together with a stronger melt-SAM anticorrelation than in our simulations. To better describe interplays, we also calculate a multi-linear regression of melt rates on the four indices (last column of Table 4). Accounting for several indices increases the explained melt rate variance compared to a single index, which indicates an interplay of the fours modes of variability. Overall, $21 \%$ to $30 \%$ of the summer melt rate variance can be explained by a linear combination of the climate indices.

The part of explained variance never exceeds $50 \%$ of the summer melt and SMB variance. Possible reasons for this are as follows. (i) The modes of variability do not explain all the variance locally; for example, the leading EOF of sea surface temperature (SST) in the equatorial Pacific (representing ENSO) only accounts for $50 \%$ to $70 \%$ of the SST variance (e.g. Roundy, 2014), meaning that the tropical convection thought to influence Antarctica is not completely described by SOI or NINO3.4. (ii) Assuming that a large part of the tropospheric circulation variability is explained by ENSO, SAM and ASL indices, there are reasons why the connection may be weaker for SMB and surface melting because of their nonlinear dependence on sea ice and evaporation in coastal regions, the evolution of snow properties, etc. (iii) Strong modulation of the southeast Pacific extratropical circulation by Rossby wave trains is not only due to the existence of El 

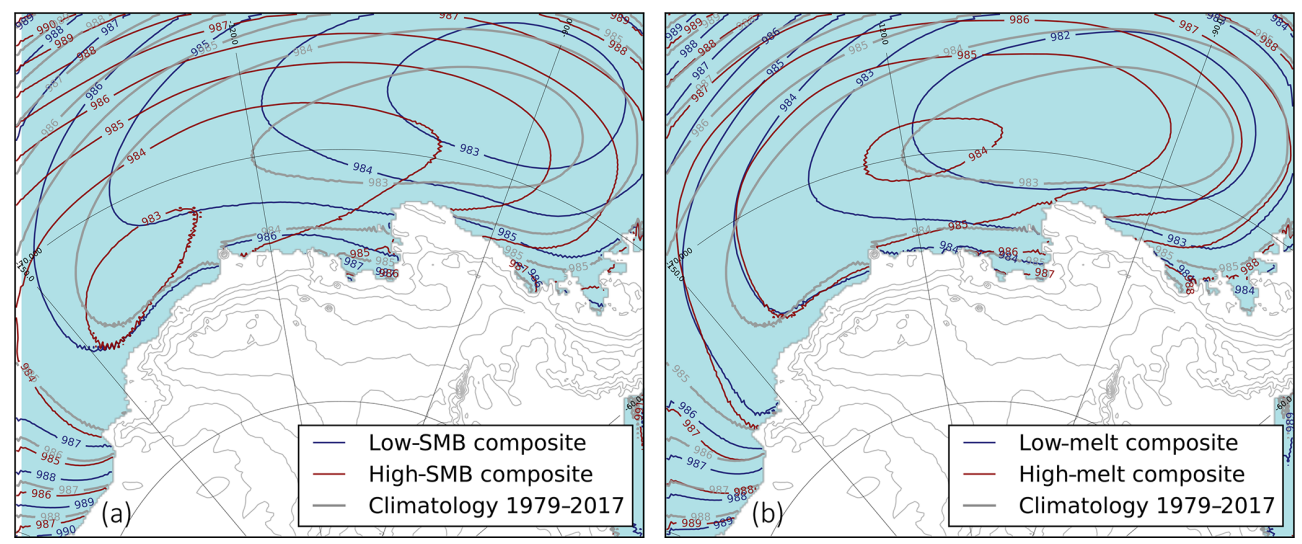

Figure 8. Summer sea surface pressure composites for high-low SMB (a) and high-low surface melt (b). The ice sheet height is indicated by thin grey contours (every $500 \mathrm{~m}$ ).

Table 2. Annual SMB decomposition for all drainage basins over 1979-2017 with SMB = snowfall + rainfall - sublimation - runoff. The middle rows indicate other terms that are not directly part of the SMB. The last two rows give snowfall and melt rates averaged over the ice shelves.

\begin{tabular}{lrrrrrrr}
\hline (mm w.e. $\mathrm{yr}^{-1}$ ) & Abbot & Cosgrove & Pine Island & Thwaites & Crosson & Dotson & Getz \\
\hline SMB & 959.5 & 660.5 & 429.1 & 504.5 & 867.7 & 895.0 & 843.0 \\
Sublimation & 26.5 & 30.3 & 12.7 & 0.6 & 22.6 & 25.6 & 22.8 \\
Snowfall & 981.9 & 688.5 & 441.3 & 505.0 & 887.6 & 919.5 & 864.9 \\
Rainfall & 4.0 & 2.3 & 0.4 & 0.1 & 2.8 & 1.1 & 0.8 \\
Runoff & 0.0 & 0.0 & 0.0 & 0.0 & 0.0 & 0.0 & 0.0 \\
\hline Refreezing & 36.4 & 27.0 & 4.3 & 1.0 & 6.2 & 7.2 & 9.6 \\
Surface melt & 32.5 & 24.8 & 3.9 & 0.9 & 3.4 & 6.1 & 8.8 \\
\hline Snowfall (only over ice shelf) & 795.4 & 296.9 & 422.7 & 811.5 & 1051.5 & 672.0 & 789.9 \\
Surface melt (only over ice shelf) & 57.9 & 83.2 & 82.0 & 26.5 & 18.5 & 23.7 & 26.7 \\
\hline
\end{tabular}

Niño events but also depends on the exact spatial distribution of deep convection in the tropical central Pacific and the strength of the polar jet (Harangozo, 2004). (iv) A part of the variability of SMB and melting may be stochastic, i.e. not necessarily driven by variability with spatiotemporal coherence at large scales.

\section{Discussion}

The composite analysis and the correlation of SMB and melt rates to the ASL indices give a consistent picture. Summers tend to be associated with high SMB when the ASL migrates westward and southward because this places the northerly flow (ASL eastern flank) over the Amundsen Sea, thereby increasing the southward humidity transport and snowfall. This corresponds to the large-scale features described by Hosking et al. (2013) but is here described for the SMB of individual drainage basins. By contrast, longitudinal migrations of the ASL are not the main driver of surface melting variability, as previously noted by Deb et al. (2018). Summers tend to be associated with high surface melt rates when the Amundsen-Bellingshausen region experiences blocking, i.e. anticyclonic conditions, which tends to decrease the climatological southerly flow (western flank of the ASL) and to favor marine air intrusions that make cloud cover denser with increasing downward longwave radiation, as described by Scott et al. (2019).

While the role of the ASL now appears to be quite clear, the exact impact of ENSO on SMB and surface melt rates remains elusive. Earlier studies analyzing the impact of ENSO on precipitation in West Antarctica had difficulties understanding the mechanisms and the robustness of the signal, because they had to rely on relatively short observation and reanalysis periods (Bromwich et al., 2000; Cullather et al., 1996; Genthon and Cosme, 2003). Using a dedicated SMB model over a longer time period, we have shown here that the ENSO-SMB relationship in austral summer exists, but it is relatively weak as SOI alone cannot explain more than $16 \%$ of the interannual variance in summer SMB. The relationship between ENSO and the number of melt days was identified by Deb et al. (2018) using both regional simulations and a satellite product. It was then thoroughly described 

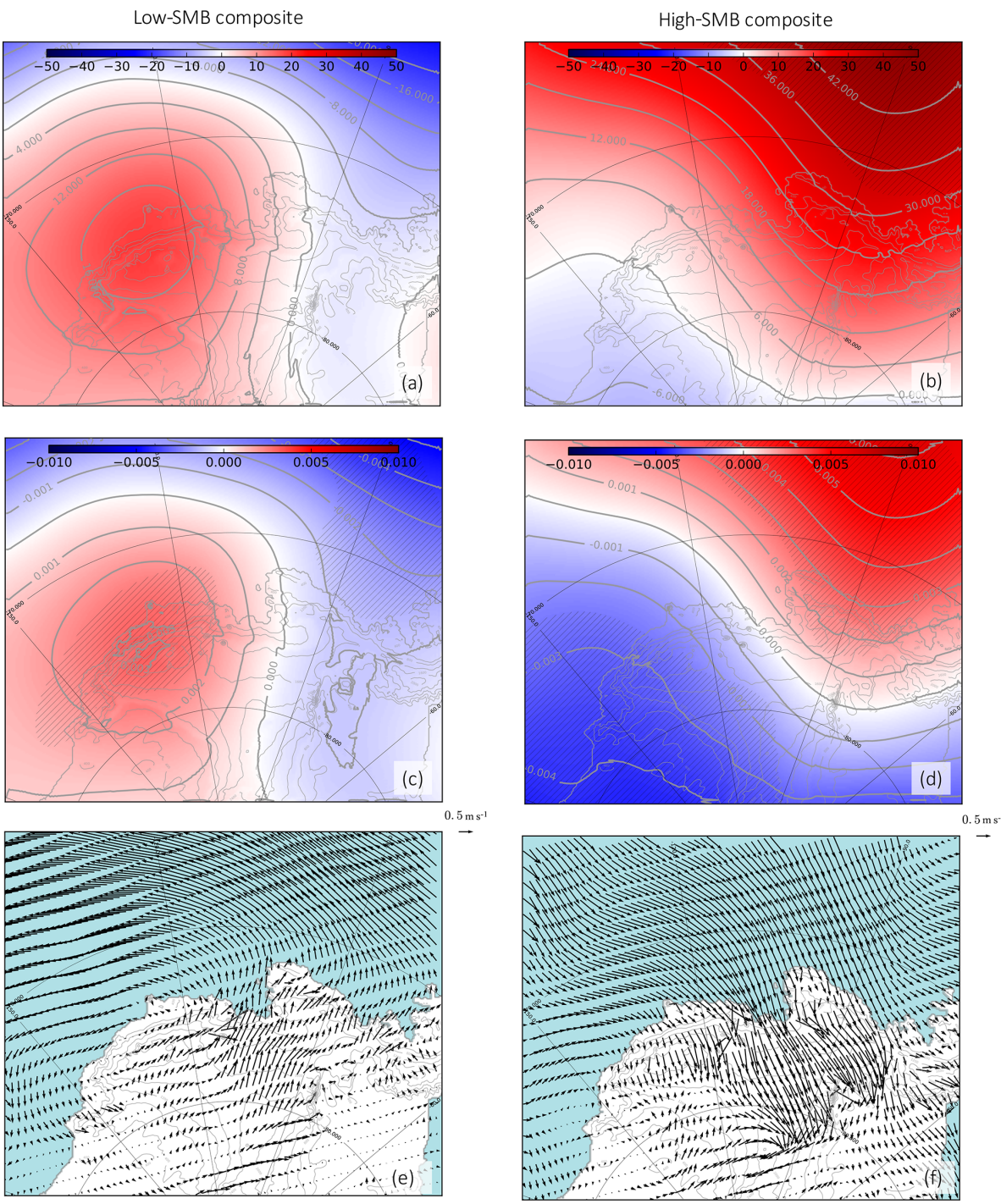

Figure 9. (a, b) The $500 \mathrm{hPa}$ geopotential height (m), (c, d) $500 \mathrm{hPa}$ geopotential height divided by the domain-averaged value for each season and (e, f) $10 \mathrm{~m}$ wind $\left(\mathrm{m} \mathrm{s}^{-1}\right)$ anomalies during low-SMB summers (left) and high-SMB summers (right); scales of arrow lengths are shown near the upper right corner of panels (e) and (f). Anomalies are calculated as high or low composites minus the climatology over 1979-2017. The hatched area (a-d) represents significance $>90 \%$ calculated with Welch's $t$ test.

Table 3. Correlation $R$ between ENSO, SAM, and ASL indices and the SMB over individual drainage basins in austral summer. The statistical significance (Welch's $t$ test) is written within brackets. The last column shows the correlation of a multi-linear regression to the four indices using a least absolute shrinkage and selection operator (LASSO; Tibshirani, 1996).

\begin{tabular}{lrrrrr}
\hline $\begin{array}{l}\text { Drainage } \\
\text { basins }\end{array}$ & $\begin{array}{r}\text { SOI vs. } \\
\text { SMB }\end{array}$ & $\begin{array}{r}\text { SAM index } \\
\text { vs. SMB }\end{array}$ & $\begin{array}{r}\text { ASL longitudinal } \\
\text { location vs. SMB }\end{array}$ & $\begin{array}{r}\text { ASL relative } \\
\text { central pressure } \\
\text { vs. SMB }\end{array}$ & $\begin{array}{r}\text { Multi-linear } \\
\text { regression }\end{array}$ \\
\hline Abbot & $0.25(87 \%)$ & $0.14(59 \%)$ & $-0.15(65 \%)$ & $-0.01(3 \%)$ & 0.40 \\
Cosgrove & $0.26(88 \%)$ & $0.16(65 \%)$ & $-0.21(80 \%)$ & $0.08(36 \%)$ & 0.46 \\
Pine Island & $0.32(95 \%)$ & $0.03(17 \%)$ & $-0.25(87 \%)$ & $-0.17(69 \%)$ & 0.47 \\
Thwaites & $0.33(96 \%)$ & $0.02(8 \%)$ & $-0.45(99 \%)$ & $-0.10(47 \%)$ & 0.57 \\
Crosson & $0.40(99 \%)$ & $-0.00(2 \%)$ & $-0.53(99 \%)$ & $-0.14(60 \%)$ & 0.66 \\
Dotson & $0.36(97 \%)$ & $0.00(2 \%)$ & $-0.61(99 \%)$ & $0.15(65 \%)$ & 0.70 \\
Getz & $0.30(93 \%)$ & $-0.15(62 \%)$ & $-0.64(99 \%)$ & $0.27(90 \%)$ & 0.68 \\
\hline
\end{tabular}


Table 4. Correlation $R$ between -SOI, SAM, and ASL indices and MAR surface melt rates (bold), MAR number of melt days (regular), number of melt days from satellite products (italic, first value for Nicolas et al. (2017) and second for Picard et al. (2007)), over individual ice shelves in summer. The statistical significance (Welch's $t$ test) is written within brackets. The last column shows the correlation of a multi-linear regression to the four indices using a least absolute shrinkage and selection operator (LASSO, Tibshirani 1996).

\begin{tabular}{|c|c|c|c|c|c|}
\hline $\begin{array}{l}\text { Drainage } \\
\text { basins }\end{array}$ & $-\mathrm{SOI}$ & $\begin{array}{l}\text { SAM } \\
\text { index }\end{array}$ & $\begin{array}{r}\text { ASL longitudinal } \\
\text { location }\end{array}$ & $\begin{array}{l}\text { ASL relative } \\
\text { central pressure }\end{array}$ & $\begin{array}{r}\text { Multi-linear } \\
\text { regression }\end{array}$ \\
\hline \multirow[t]{4}{*}{ Abbot } & $0.23(84 \%)$ & $-0.05(24 \%)$ & $-0.25(86 \%)$ & $0.35(97 \%)$ & 0.46 \\
\hline & $0.25(86 \%)$ & $-0.04(19 \%)$ & $-0.23(84 \%)$ & $0.30(93 \%)$ & 0.44 \\
\hline & $0.37(97 \%)$ & $-0.22(79 \%)$ & $-0.29(91 \%)$ & $0.32(94 \%)$ & 0.49 \\
\hline & $0.37(98 \%)$ & $-0.18(71 \%)$ & $-0.18(72 \%)$ & $-0.24(92 \%)$ & 0.47 \\
\hline \multirow[t]{4}{*}{ Cosgrove } & $0.24(86 \%)$ & $-\mathbf{0 . 0 8}(36 \%)$ & $-\mathbf{0 . 3 0}(93 \%)$ & $0.37(98 \%)$ & 0.50 \\
\hline & $0.25(87 \%)$ & $-0.06(29 \%)$ & $-0.29(92 \%)$ & $0.32(95 \%)$ & 0.47 \\
\hline & $0.37(97 \%)$ & $-0.20(76 \%)$ & $-0.37(97 \%)$ & $0.32(94 \%)$ & 0.52 \\
\hline & $0.38(98 \%)$ & $-0.25(87 \%)$ & $-0.16(65 \%)$ & $0.27(90 \%)$ & 0.46 \\
\hline \multirow[t]{4}{*}{ Pine Island } & $0.30(86 \%)$ & $-0.07(33 \%)$ & $-0.31(94 \%)$ & $0.38(98 \%)$ & 0.54 \\
\hline & $0.29(92 \%)$ & $-0.03(13 \%)$ & $-0.34(96 \%)$ & $0.35(97 \%)$ & 0.55 \\
\hline & $0.48(99 \%)$ & $-0.29(91 \%)$ & $-0.21(78 \%)$ & $0.42(99 \%)$ & 0.62 \\
\hline & $0.44(99 \%)$ & $-0.19(75 \%)$ & $-0.13(56 \%)$ & $0.37(98 \%)$ & 0.59 \\
\hline \multirow[t]{4}{*}{ Thwaites } & $0.29(92 \%)$ & $-0.13(56 \%)$ & $-0.25(87 \%)$ & $0.39(98 \%)$ & 0.51 \\
\hline & $0.35(95 \%)$ & $-0.11(43 \%)$ & $-0.19(69 \%)$ & $0.51(99 \%)$ & 0.67 \\
\hline & $0.48(99 \%)$ & $-0.23(81 \%)$ & $-0.11(45 \%)$ & $0.29(91 \%)$ & 0.55 \\
\hline & $0.44(99 \%)$ & $-0.28(89 \%)$ & $-0.06(26 \%)$ & $0.26(87 \%)$ & 0.52 \\
\hline \multirow[t]{4}{*}{ Crosson } & $0.28(91 \%)$ & $-0.14(60 \%)$ & $-0.23(84 \%)$ & $0.41(99 \%)$ & 0.51 \\
\hline & $0.29(86 \%)$ & $-0.08(30 \%)$ & $-0.11(42 \%)$ & $0.40(97 \%)$ & 0.52 \\
\hline & $0.48(99 \%)$ & $-0.35(95 \%)$ & $-0.20(76 \%)$ & $0.39(98 \%)$ & 0.61 \\
\hline & $0.35(96 \%)$ & $-0.35(96 \%)$ & $-0.10(45 \%)$ & $0.41(98 \%)$ & 0.52 \\
\hline \multirow[t]{4}{*}{ Dotson } & $0.27(90 \%)$ & $-0.14(60 \%)$ & $-0.24(86 \%)$ & $0.42(99 \%)$ & 0.52 \\
\hline & $0.26(86 \%)$ & $-0.13(54 \%)$ & $-0.25(86 \%)$ & $0.44(99 \%)$ & 0.53 \\
\hline & $0.36(95 \%)$ & $-0.27(84 \%)$ & $-0.03(11 \%)$ & $0.36(94 \%)$ & 0.52 \\
\hline & $0.33(93 \%)$ & $-0.28(86 \%)$ & $0.13(51 \%)$ & $0.32(91 \%)$ & 0.50 \\
\hline \multirow[t]{4}{*}{ Getz } & $0.22(82 \%)$ & $-0.16(65 \%)$ & $-0.26(88 \%)$ & $0.46(99 \%)$ & 0.53 \\
\hline & $0.22(82 \%)$ & $-0.16(67 \%)$ & $-0.29(92 \%)$ & $0.46(99 \%)$ & 0.54 \\
\hline & $0.50(99 \%)$ & $-0.42(99 \%)$ & $-0.24(84 \%)$ & $0.41(99 \%)$ & 0.64 \\
\hline & $0.34(96 \%)$ & $-0.41(98 \%)$ & $-0.15(63 \%)$ & $0.34(96 \%)$ & 0.46 \\
\hline
\end{tabular}

by Scott et al. (2019), who found that SOI could explain $20 \%$ of the melt variance when considering all the Amundsen ice shelves together and using satellite products (correlation of 0.45 in their Table 3). While we obtain results similar to those of Scott et al. (2019) when using the number of melt days derived from satellite products, both the number of melt days and the melt rates simulated by MAR indicate less variance explained by SOI, that is, between $5 \%$ and $9 \%$ for the individual drainage basins. Our MAR simulations certainly contain biases in the representation of the melting process and the way it affects surface properties such as albedo and roughness, but it is also possible that the number of melt days derived from microwave satellite data is biased due to variability in surface conditions, percolation within fresh snow, meltwater ponding (observed on Pine Island; Kingslake et al., 2017) and satellite overpass time (Tedesco, 2009; Scott et al., 2019). More work will be needed to understand these differences.

Numerous publications have explained the remote effects of ENSO on the West Antarctic climate through Rossby wave trains that connect the convective anomalies associated with ENSO in the equatorial Pacific to Antarctica (e.g., Yuan and Martinson, 2001). However, austral winter and spring conditions are more favorable for Rossby wave trains to be formed and to propagate to high southern latitudes than summer conditions (Harangozo, 2004; Lachlan-Cope and Connolley, 2006; Ding et al., 2011, and references therein). The poleward propagation of tropically sourced Rossby waves in summer is indeed inhibited by the strong polar front jet in the South Pacific sector at that time of the year, which leads to Rossby wave reflection away from the Amundsen Sea region (Scott Yiu and Maycock, 2019). This lack of direct 

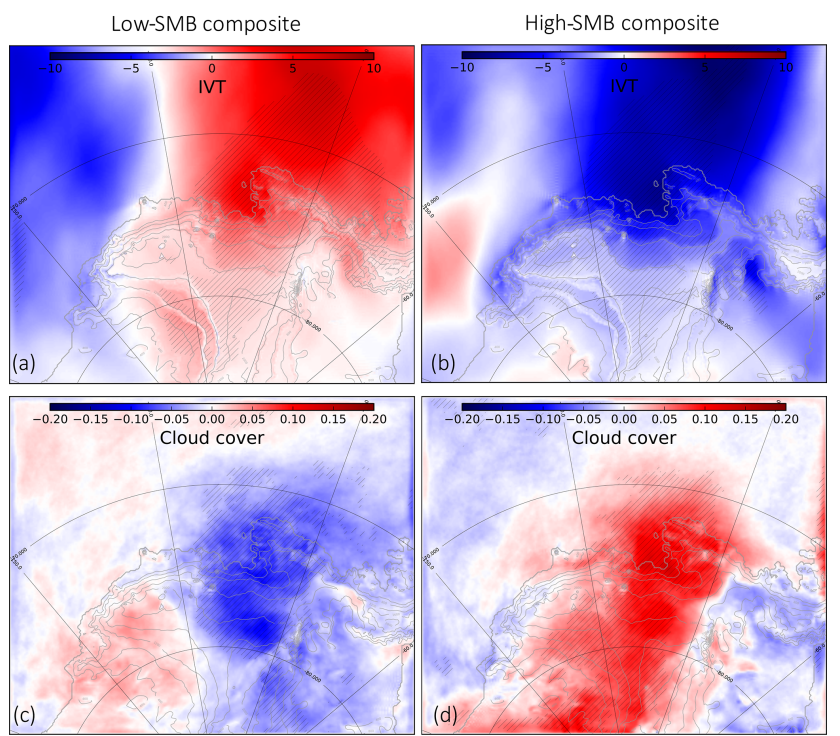

Figure 10. (a, b) Vertical integrated vapor transport (IVT) along the $y$ axis (negative toward the continent) calculated as IVT $\left[\mathrm{kg} \mathrm{m}^{-2}\right]=\int_{925}^{700} q \cdot v \frac{\mathrm{d} P}{g}$, with $q$ the specific humidity $\left(\mathrm{g} \mathrm{kg}^{-1}\right)$, $v$ the wind speed $\left(\mathrm{m} \mathrm{s}^{-1}\right), P$ the pressure $(\mathrm{Pa})$, and $g$ the gravity $\left(9.81 \mathrm{~m} \mathrm{~s}^{-2}\right.$ ) and (c, $\left.\mathbf{d}\right)$ cloud cover (no units, from 0 to 1 ) anomalies during low-SMB summers (left) and high-SMB summers (right). Anomalies are calculated as high or low composites minus the climatology over 1979-2017. The hatched area represents significance $>90 \%$ calculated with Welch's $t$ test.

connection in summer was supported by Steig et al. (2012), who found the weakest correlations between NINO3.4 and wind stress anomalies in the Amundsen Sea in DJF compared to other seasons. Therefore, we investigated possible lags in the relationships to ENSO. While ENSO peaks in DJF, it starts to develop in MAM (March-April-May), as indicated by the growing SOI autocorrelation from a 9- to 6-month lag (Fig. 13a). The first implication of this is that any signal correlated to SOI in DJF will be correlated to SOI in the previous JJA without the need for a lagged physical mechanism. Nevertheless, the correlation between SMB or melt rates in DJF and SOI in the preceding JJA is higher than the synchronous correlation for all the drainage basins (solid curves in Fig. 13b-h), which suggests that the lagged relationship is not only a simple statistical artifact. The results of Ding et al. (2011) and Steig et al. (2012) suggest that there could be a lagged mechanism whereby ENSO would influence West Antarctica in austral spring or winter, with a delayed response of SMB and melting in the following austral summer. The number of melt days derived from satellite data also gives 6-month-lagged correlations to SOI that are as high or higher than synchronous correlations for most ice shelves (dashed curves in Fig. 13b-h).

We now discuss possible explanations for this lag. As mentioned previously, the Rossby wave trains connecting the equatorial Pacific to Antarctica are expected to develop
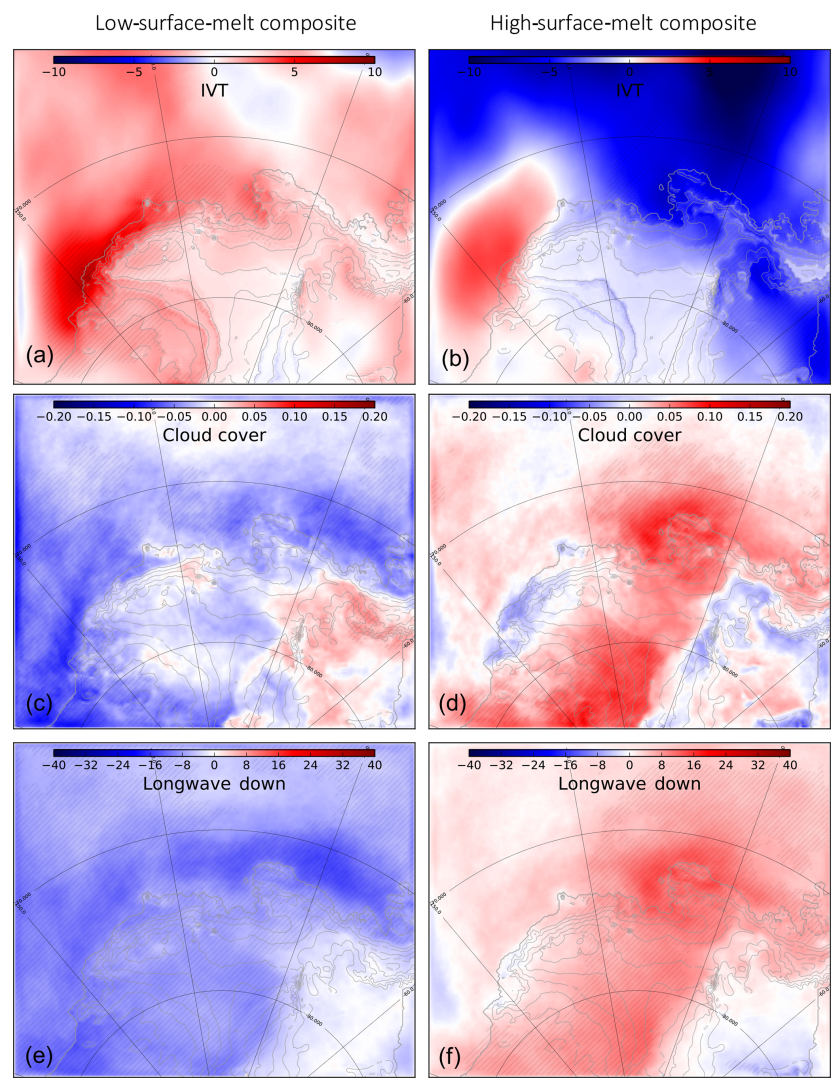

Figure 11. (a, b) Vertical integrated vapor transport (IVT) along the $y$ axis (negative toward the continent $\left(\mathrm{kg} \mathrm{m}^{-2}\right.$, same formula as for Fig. 10), (c, d) cloud cover (no units, from 0 to 1) and (e, f) downward longwave radiation $\left(\mathrm{W} \mathrm{m}^{-2}\right)$ anomalies during lowmelt summers (left) and high-melt summers (right). Anomalies are calculated as high or low composites minus the climatology over 1979-2017. The hatched area represents significance $>90 \%$ calculated with Welch's $t$ test.

within a few weeks in response to ENSO convective anomalies (e.g. Hoskins and Karoly, 1981; Mo and Higgins, 1998; Peters and Vargin, 2015). Therefore, the lag has to come from anomalies stored in a slower medium, such as snowpack, ocean or sea ice. Snow surface melting in DJF is correlated neither to the temperature of snow layers within the first $2 \mathrm{~m}$ in the previous months (not shown) nor to the snow accumulated over the previous months (not shown). This indicates that heat diffusion in snow or preconditioned porosity or albedo of snow is not responsible for the 6-month lag. By contrast, we find that El Niño events in JJA significantly reduce the sea ice cover in the following DJF (Fig. 14). This is reminiscent of Clem et al. (2017), who found stronger lagged correlation between SON ENSO and DJF sea ice cover than synchronous correlation in DJF, with consequences on summer air temperatures. We suggest two possible explanations for this lagged ENSO-sea ice relationship. First, it could be slowly advected from the Ross Sea. Pope et al. (2017) indeed found that El Niño events develop- 

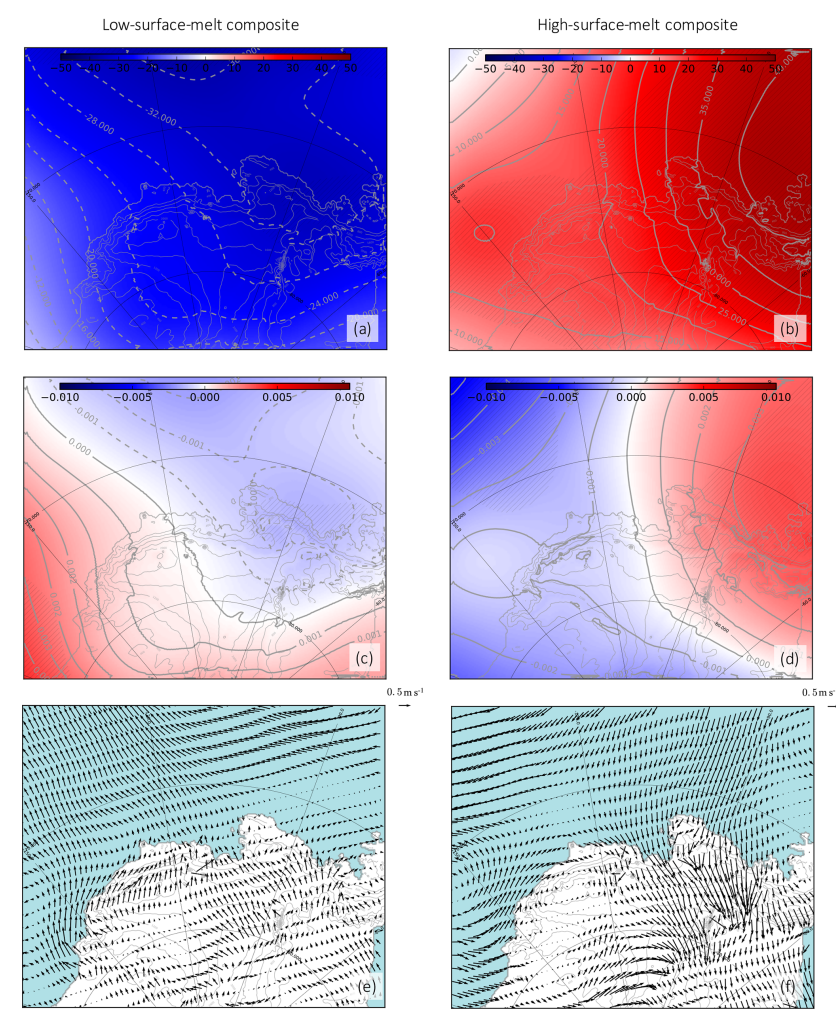

Figure 12. (a, b) The $500 \mathrm{hPa}$ geopotential height (m) and (c, d) $500 \mathrm{hPa}$ geopotential height divided by the domain-averaged value for each season and (e, f) $10 \mathrm{~m}$ wind $\left(\mathrm{m} \mathrm{s}^{-1}\right)$ anomalies during low-melt summers (left) and high-melt summers (right); scales of arrow lengths are shown near the upper right corner of panels (e) and (f). Anomalies are calculated as high or low composites minus the climatology over 1979-2017. The hatched area represents significance $>90 \%$ calculated with Welch's $t$ test.

ing in MAM created a dipole of sea ice anomalies, with decreased (increased) concentration in the Ross Sea (Amundsen and Bellingshausen seas). Using a novel sea ice budget analysis, they showed that the decreased concentration in the Ross Sea was then advected eastward, reaching the Amundsen Sea in SON and DJF.

There is also another possible pathway for a lagged ENSO-sea ice relationship. The zonal wind stress over the Amundsen Sea continental shelf break is a good proxy for the transport of Circumpolar Deep Water (CDW) onto the continental shelf (Thoma et al., 2008; Holland et al., 2019). Steig et al. (2012) noted significant correlations between wind stress and ENSO in JJA and SON but not in DJF. All these studies as well as Paolo et al. (2018) pointed out scales of a few months for the buildup and advection of CDW on the continental shelf and then into the ice shelf cavities where they produce basal melting, and Paolo et al. (2018) reported correlations between ENSO and ice shelf thinning 6 months later. As stronger ice shelf melt rates tend to decrease sea ice in this region due to the entrainment of warm CDW towards the surface (Jourdain et al., 2017; Merino et al., 2018), the connection through CDW intrusions may also explain a part of the lag between ENSO and DJF sea ice in the Amundsen Sea. We suggest that both mechanisms (eastward advection of sea ice anomalies and anomalous intrusions of CDW) may explain the 6-month lag between DJF SMB or melting and ENSO, and we leave the details of the ocean-sea ice processes for future research.

Beyond the ASL and ENSO, we also find that the SAM is not significantly related to summer SMB and surface melt over individual drainage basins at interannual timescales, which agrees with Deb et al. (2018). This may appear contradictory to the results obtained by Medley and Thomas (2019), showing that the positive SAM trend from 1957 to 2000 largely explains the pattern of annual SMB trends over the Antarctic ice sheet. First of all, their residual SMB trend (i.e. not related to SAM) is particularly strong in the Amundsen Sea Embayment (their Fig. 1e), highlighting that only a part of the SMB trend in that region may be related to the SAM trend. The multi-decadal SAM trend is also related to ozone depletion and emissions of greenhouse gases, and the interannual SAM variability may have different characteristics and impacts on SMB. Furthermore, the absence of a SMB-SAM relationship in our MAR simulations is specific to the austral summer, which represents $15 \%$ of the annual SMB, and correlations are more significant for the other seasons (Table S3). Therefore, the significant SAMSMB relationship suggested by Medley and Thomas (2019) for annual SMB is not necessarily contradictory to our results. Lastly, previous studies have suggested that the SAMENSO anticorrelation may diminish the impact of ENSO on surface melting and SMB. Partial correlations used to disentangle the SAM and ENSO influences on SMB do indicate a slightly stronger SMB-ENSO correlation when the effect of SAM is removed (in particular for Abbot and Cosgrove; see second and third columns of Table 5), but the effect is relatively small. For melt rates, the SAM modulation is very weak for all the basins (Table 5, fourth and fifth columns).

Lastly, we discuss the relationship between surface melt and snowfall over the ice shelves of the Amundsen sector (last rows of Table 2). According to Table 2, runoff is null over all the ice shelves, which means that the firn is never saturated. In other words, all surface meltwater and rainfall refreeze within the firn. This is consistent with Pfeffer et al. (1991), who estimated that the melt rate needed to saturate the firn with water and lead to hydrofracturing can be estimated as 0.7 times the snowfall rate (both melt and snowfall rates expressed in kilograms per square meter per second or millimeter water equivalent). This indicates that meltwater ponding and complex surface hydrological flows are unlikely to develop over West Antarctic ice shelves under the current climate. To reach saturation at the scale of the entire ice shelf in the future (and therefore to initiate hydrofracturing), the 0.7 ratio of Pfeffer et al. (1991) suggests that melt 
Table 5. Partial correlation of -SOI vs. SMB or melt rates, removing the influence of SAM (columns 2 and 4). Corresponding full correlations are indicated in columns 3 and 5 (same as Tables 3 and 4).

\begin{tabular}{lrrrrr}
\hline $\begin{array}{l}\text { Drainage } \\
\text { basins }\end{array}$ & $\begin{array}{r}\text { Partial correlation } \\
\text {-SOI vs. SMB } \\
\text { (without SAM) }\end{array}$ & -SOI vs. SMB & -SOI vs. SMB & $\begin{array}{r}\text { Partial correlation } \\
\text {-SOI vs. surface melt } \\
\text { (without SAM) }\end{array}$ & $\begin{array}{r}\text { Correlation - SOI } \\
\text { vs. surface melt }\end{array}$ \\
\hline Abbot & 0.36 & 0.25 & 0.21 & 0.23 & 0.23 \\
Cosgrove & 0.37 & 0.26 & 0.21 & 0.23 & 0.24 \\
Pine Island & 0.38 & 0.32 & 0.26 & 0.30 & 0.30 \\
Thwaites & 0.38 & 0.33 & 0.23 & 0.25 & 0.29 \\
Crosson & 0.45 & 0.40 & 0.29 & 0.24 & 0.28 \\
Dotson & 0.40 & 0.36 & 0.25 & 0.23 & 0.27 \\
Getz & 0.26 & 0.30 & 0.18 & 0.17 & 0.22 \\
\hline
\end{tabular}
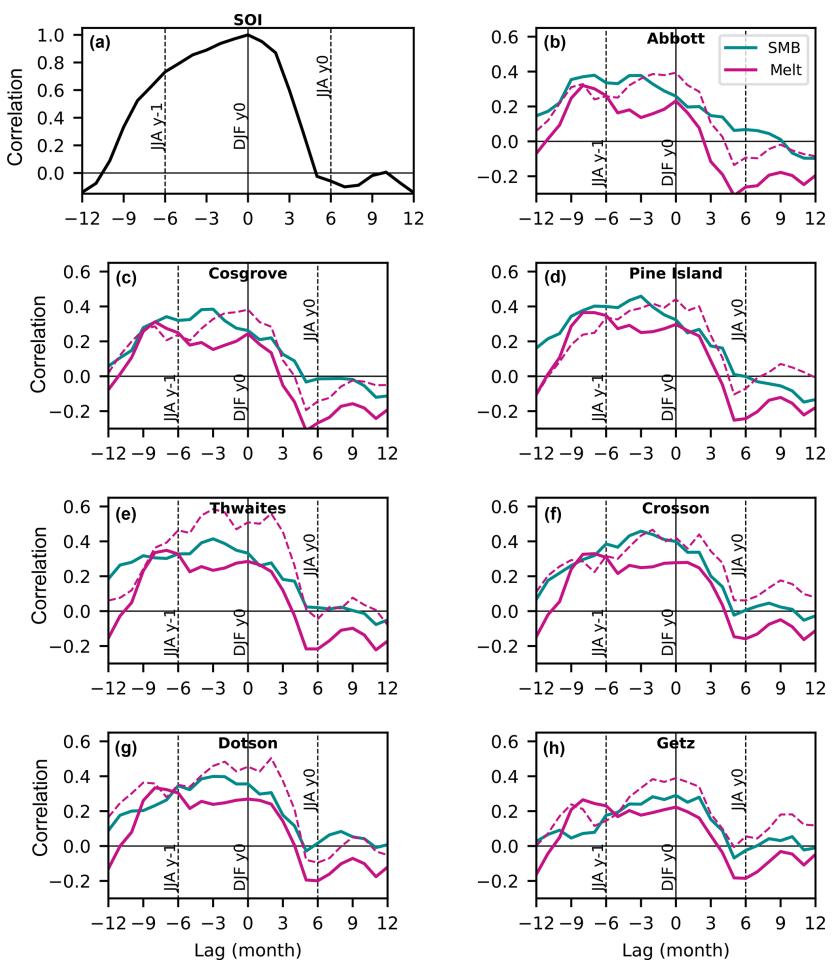

Figure 13. Correlation between lagged 3-month averaged -SOI (i.e. DJF at zero lag, previous JJA at $-6 \mathrm{lag}$ ) and (a) DJF SOI. (b-h) Simulated SMB and melt rates in individual drainage basins. The dashed curves correspond to the number of melt days derived from satellite data by Picard et al. (2007).

rates would need to be multiplied by 2.5 (Cosgrove) to 40 (Crosson) compared to present conditions.

\section{Conclusions}

In this paper we have analyzed possible drivers for summer surface melt and SMB interannual variability over the last decades in the Amundsen sector, West Antarctica. For this, we have simulated the 1979 to 2017 period with the Re-

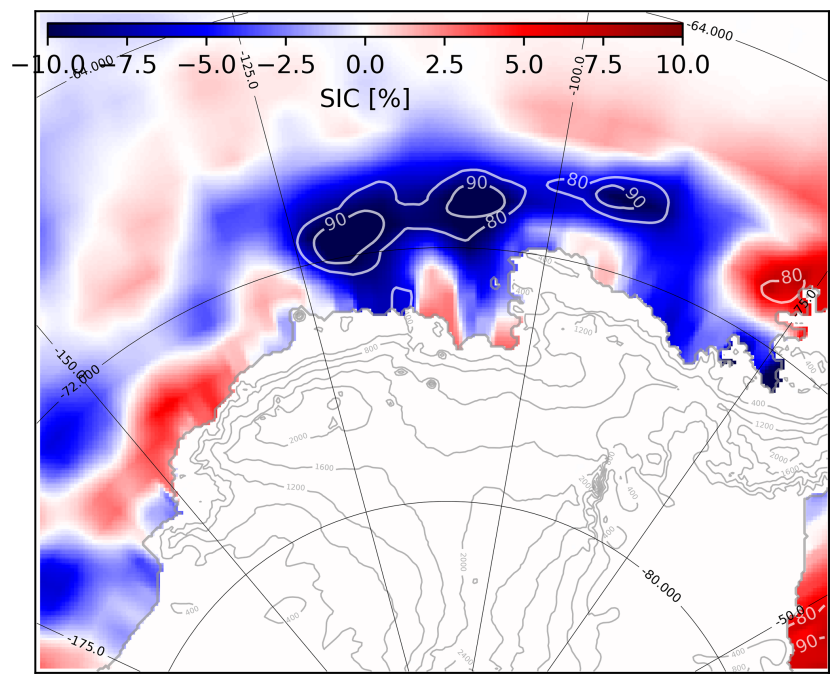

Figure 14. Summer sea ice cover (\%) anomaly (composites minus the climatology over 1979-2017) during El Niño events in JJA (6 months before). Contours represent significance with Welch's $t$ test.

gional Atmosphere Model, MAR. We have first evaluated our model configuration in comparison to observational products (i.e. AWS, airborne-radar and firn-core SMB, melt days from satellite microwave, and melt rates from satellite scatterometer). MAR gives good results for near-surface temperatures (mean overestimation of $0.10^{\circ} \mathrm{C}$ ), near-surface wind speeds (mean underestimation of $0.42 \mathrm{~m} \mathrm{~s}^{-1}$ ) and SMB (local relative bias $<20 \%$ over the Thwaites basin). The mean surface melt rate over the Amundsen Sea region is underestimated by $18 \%$ compared to the estimates derived from QuickSCAT (Trusel et al., 2013), and the interannual variability of surface melting is relatively well reproduced in terms of melt rate $(R=0.80)$ or number of melt days $(R=0.43$ to 0.69 depending on the satellite product) as also found by previous studies using the same MAR version (i.e. Datta et al., 2019). Similar underestimation was also found in another regional atmospheric model of the Amundsen region (underestimation of $30 \%-50 \%$ found by Lenaerts et al., 2017). Overall, 
our results indicate that MAR is a suitable tool to study interannual variability in the Amundsen sector.

Then, we have analyzed the interannual variability of summer SMB. The strongest summer SMB occurs over Thwaites and Pine Island glaciers when the ASL migrates far westward (by typically $30^{\circ}$ ) and southward (by typically $3-4^{\circ}$ ). This promotes a southward flow on the eastern flank of the ASL, towards the glaciers, with resulting increased moisture convergence, precipitation and therefore SMB. Our study hence provides further support for the connection between Antarctic precipitation and the ASL longitudinal position that was previously described by Hosking et al. (2013) based on the ERA-Interim reanalysis. In terms of climate indices, this corresponds to an anticorrelation between SMB and the ASL longitudinal position. This anticorrelation is found for all the drainage basins of the Amundsen Sea Embayment, and the part of the SMB variance explained by the ASL longitudinal migrations ranges from $2 \%$ to $41 \%$ (increasing westward). A small part of the SMB variance is also related to ENSO, with higher SMB during El Niño events and lower SMB during La Niña, but less than $8 \%$ of the SMB variance is explained by ENSO variability. This SMB connection to ENSO is independent from its connection with the ASL longitudinal position.

We have also analyzed the interannual variability of summer surface melt rates. The strongest surface melting occurs over Thwaites and Pine Island glaciers when the ASL undergoes an anticyclonic anomaly (likely the signature of blocking activity), which is visible through anomalies of the ASL relative central pressure. Such an anomaly promotes a southward anomaly of near-surface winds and moisture convergence over the Amundsen Sea Embayment. As recently described by Scott et al. (2019), this leads to increased cloud cover and downward longwave radiation, which in turn increases surface melting. As for SMB, we do not find that surface melt rate variability in our simulations is strongly connected to ENSO as it does not explain more than $9 \%$ of the total variance in simulated summer surface melt rate (or $12 \%$ of the number of melt days). By contrast and for unknown reasons, the variance in number of melt days derived from satellite products indicates that as much as $25 \%$ of the variance in these products could be explained by $-\mathrm{SOI}$.

We also suggest that at least a part of the ENSO-SMB and ENSO-melt relationships in summer is inherited from the previous austral winter (JJA). Rossby wave trains generated by convective anomalies related to developing El Niño events in austral winter significantly affect the Antarctic region, and we suggest that this has some impact on SMB and surface melting in the Amundsen sector 6 months later. Such a delay could be related either to sea ice anomalies generated by ENSO in the Ross Sea in austral winter and taking 6 months to be advected to the Amundsen Sea (Pope et al., 2017) or to marine intrusions of Circumpolar Deep Water that are favored by El Niño events in austral winter (Steig et al., 2012). Circumpolar Deep Water may take 6 months to reach ice shelf cavities where increased basal melting favors the entrainment of this water towards the ocean surface (Jourdain et al., 2017). It should nonetheless be noted that even accounting for this 6-month lag, the influence of ENSO on summer SMB and melt rates remains weak, not explaining more than $15 \%$ variance.

Lastly, we propose that the rate of surface water needed to saturate the firn and lead to hydrofracturing has to increase by a factor of 2.5 to 40 depending on the ice shelf. Such an increase could be reached under strong warming scenarios given the exponential temperature dependence described by Trusel et al. (2015), although snowfall is also expected to increase (Krinner et al., 2008; Agosta et al., 2013; Ligtenberg et al., 2013; Lenaerts et al., 2016; Palerme et al., 2017), requiring even more meltwater to reach saturation. In their projections, Kuipers Munneke et al. (2014) found that the western part of Abbot as well as Cosgrove could become watersaturated before the end of the twenty-second century, but the other ice shelves of the Amundsen sector remained nonsaturated. Further work will be needed to assess the robustness of these projections, with other firn models and global projections.

Code and data availability. The MAR code (version 3.9.1) is available on the MAR website (http://mar.cnrs.fr/, last access: 17 January 2020); outputs from the Amundsen simulation presented in this study are available on https://doi.org/10.5281/zenodo.2815907.

Supplement. The supplement related to this article is available online at: https://doi.org/10.5194/tc-14-229-2020-supplement.

Author contributions. The study was designed by MD-M and NCJ. Setup of the MAR domain configuration was made by MD-M, CA, $\mathrm{AD}$ and NCJ. CA, XF, HG, CK and CA developed and tuned the MAR model for Antarctica, and they contributed to improving and interpreting our simulations. CK developed the scripts used to compare MAR to AWS data. JDW and VF contributed to the interpretation of our results related to interannual variability. All the authors significantly contributed to this paper.

Competing interests. The authors declare that they have no conflict of interest

Acknowledgements. This work was funded by the French National Research Agency (ANR) through the TROIS-AS (ANR-15-CE010005-01) project. The development of MAR was partly funded by Labex OSUG@2020 (ANR10 LABX56) through the "Tout le Monde se MAR" project. All the computations presented in this paper were performed using the GRICAD infrastructure (https:// gricad.univ-grenoble-alpes.fr, last access: 17 January 2020), which is partly supported by the Equip@Meso project (ANR-10-EQPX29-01) of the program "Investissements d'Avenir" supervised by 
ANR, by the Rhône-Alpes region (GRANT CPER07_13 CIRA: http://www.ci-ra.org, last access: last access: 17 January 2020) and by France-Grilles (http://www.france-grilles.fr, last access: last access: 17 January 2020). We thank Ghislain Picard, Luke Trusel, Julien Nicolas, Yetang Wang and Brooke Medley for making their data available.

Financial support. This research has been supported by the French National Research Agency (ANR) (grant no. ANR-15-CE01-000501), the Labex OSUG@2020 (grant no. ANR10 LABX56) and the ANR-10-EQPX-29-01 (grant no. CPER07_13 CIRA: http://www. ci-ra.org).

Review statement. This paper was edited by Kenichi Matsuoka and reviewed by two anonymous referees.

\section{References}

Agosta, C., Favier, V., Krinner, G., Gallée, H., Fettweis, X., and Genthon, C.: High-resolution modelling of the Antarctic surface mass balance, application for the twentieth, twenty first and twenty second centuries, Clim. Dynam., 41, 3247-3260, https://doi.org/10.1007/s00382-013-1903-9, 2013.

Agosta, C., Amory, C., Kittel, C., Orsi, A., Favier, V., Gallée, H., van den Broeke, M. R., Lenaerts, J. T. M., van Wessem, J. M., van de Berg, W. J., and Fettweis, X.: Estimation of the Antarctic surface mass balance using the regional climate model MAR (19792015 ) and identification of dominant processes, The Cryosphere, 13, 281-296, https://doi.org/10.5194/tc-13-281-2019, 2019.

Amory, C., Trouvilliez, A., Gallée, H., Favier, V., Naaim-Bouvet, F., Genthon, C., Agosta, C., Piard, L., and Bellot, H.: Comparison between observed and simulated aeolian snow mass fluxes in Adélie Land, East Antarctica, The Cryosphere, 9, 1373-1383, https://doi.org/10.5194/tc-9-1373-2015, 2015.

Asay-Davis, X. S., Jourdain, N. C., and Nakayama, Y.: Developments in simulating and parameterizing interactions between the Southern Ocean and the Antarctic Ice sheet, Curr. Clim. Change Rep., 3, 316-329, https://doi.org/10.1007/s40641-0170071-0, 2017.

Bell, R. E., Banwell, A. F., Trusel, L. D., and Kingslake, J.: Antarctic surface hydrology and impacts on icesheet mass balance, Nat. Clim. Change, 8, 1044-1052, https://doi.org/10.1038/s41558-018-0326-3, 2018.

Bracegirdle, T. J., Connolley, W. M., and Turner, J.: Antarctic climate change over the twenty first century, J. Geophys. Res.Atmos., 113, D03103, https://doi.org/10.1029/2007jd008933, 2008.

Bromwich, D. H., Rogers, A. N., Kåallberg, P., Cullather, R. I., White, J. W., and Kreutz, K. J.: ECMWF analyses and reanalyses depiction of ENSO signal in Antarctic precipitation, J. Climate, 13, 1406-1420, https://doi.org/10.1175/15200442(2000)013<1406:EAARDO>2.0.CO;2, 2000.

Bromwich, D. H., Nicolas, J. P., and Monaghan, A. J.: An Assessment of Precipitation Changes over Antarctica and the Southern Ocean since 1989 in Contemporary Global Reanalyses, J. Climate, 24, 4189-4209, 2011.
Bromwich, D. H., Nicolas, J. P., Monaghan, A. J., Lazzara, M. A., Keller, L. M., Weidner, G. A., and Wilson, A. B.: Central West Antarctica among the most rapidly warming regions on Earth, Nat. Geosci., 6, 139-145, https://doi.org/10.1038/ngeo1671, 2013.

Brun, E., David, P., Sudul, M., and Brunot, G.: A numerical model to simulate snow-cover stratigraphy for operational avalanche forecasting, J. Glaciol., 38, 13-22, https://doi.org/10.1017/s0022143000009552, 1992.

Cai, W., Borlace, S., Lengaigne, M., Van Rensch, P., Collins, M., Vecchi, G., Timmermann, A., Santoso, A., McPhaden, M. J., Wu, L., England, M. H., Wang, G., Guilyardi, E., and Jin, F.-F.: Increasing frequency of extreme El Niño events due to greenhouse warming, Nat. Clim. change, 4, 111-116, https://doi.org/10.1038/nclimate2100, 2014.

Cai, W., Wang, G., Santoso, A., Lin, X., and Wu, L.: Definition of extreme El Niño and its impact on projected increase in extreme El Niño frequency, Geophys. Res. Lett., 44, 11184-11190, https://doi.org/10.1002/2017gl075635, 2017.

Chen, G. and Held, I. M.: Phase speed spectra and the recent poleward shift of Southern Hemisphere surface westerlies, Geophys. Res. Lett., 34, L21805, doi;10.1029/2007g1031200 , 2007.

Clem, K. R., Renwick, J. A., and McGregor, J.: Large-Scale Forcing of the Amundsen Sea Low and Its Influence on Sea Ice and West Antarctic Temperature, J. Climate, 30, 8405-8424, https://doi.org/10.1175/JCLI-D-16-0891.1, 2017.

Cullather, R. I., Bromwich, D. H., and Van Woert, M. L.: Interannual variations in Antarctic precipitation related to El NiñoSouthern Oscillation, J. Geophys. Res.-Atmos., 101, 1910919118, https://doi.org/10.1029/96jd01769, 1996.

Datta, R. T., Tedesco, M., Fettweis, X., Agosta, C., Lhermitte, S., Lenaerts, J., and Wever, N.: The Effect of FoehnInduced Surface Melt on Firn Evolution Over the Northeast Antarctic Peninsula, Geophys. Res. Lett., 46, L21805, https://doi.org/10.1029/2018GL080845, 2019.

Deb, P., Orr, A., Bromwich, D. H., Nicolas, J. P., Turner, J., and Hosking, J. S.: Summer drivers of atmospheric variability affecting ice shelf thinning in the Amundsen Sea Embayment, West Antarctica, Geophys. Res. Lett., 45, 4124-4133, https://doi.org/10.1029/2018g1077092, 2018.

Deconto, R. M. and Pollard, D.: Contribution of Antarctica to past and future sea-level rise, Nature, 531, 591-597, https://doi.org/10.1038/nature17145, 2016.

Dee, D. P., Uppala, S. M., Simmons, A. J., Berrisford, P., Poli, P., Kobayashi, S., Andrae, U., Balmaseda, M. A., Balsamo, G., Bauer, P., Bechtold, P., Beljaars, A. C. M., van de Berg, I., Biblot, J., Bormann, N., Delsol, C., Dragani, R., Fuentes, M., Greer, A. J., Haimberger, L., Healy, S. B., Hersbach, H., Holm, E. V., Isaksen, L., Kallberg, P., Kohler, M., Matricardi, M., McNally, A. P., Mong-Sanz, B. M., Morcette, J.-J., Park, B.-K., Peubey, C., de Rosnay, P., Tavolato, C., Thepaut, J. N., and Vitart, F.: The ERAInterim reanalysis: Configuration and performance of the data assimilation system, Q. J. Roy. Meteorol. Soc., 137, 553-597, https://doi.org/10.1002/qj.493, 2011.

De Ridder, K. and Gallée, H.: Land surface-induced regional climate change in southern Israel, J. Appl. Meteorol., 37, 1470-1485, https://doi.org/10.1175/15200450(1998)037<1470:LSIRCC>2.0.CO;2, 1998. 
Deser, C., Phillips, A. S., Tomas, R. A., Okumura, Y. M., Alexander, M. A., Capotondi, A., Scott, J. D., Kwon, Y.-O., and Ohba, M.: ENSO and Pacific Decadal Variability in the Community Climate System Model Version 4, J. Climate, 25, 2622-2651, https://doi.org/10.1175/jcli-d-11-00301.1, 2012.

Ding, Q., Steig, E. J., Battisti, D. S., and Küttel, M.: Winter warming in West Antarctica caused by central tropical Pacific warming, Nat. Geosci., 4, 398, https://doi.org/10.1038/ngeo1129, 2011.

Dutrieux, P., De Rydt, J., Jenkins, A., Holland, P. R., Ha, H. K., Lee, S. H., Steig, E. J., Ding, Q., Abrahamsen, E. P., and Schröder, M.: Strong sensitivity of Pine Island iceshelf melting to climatic variability, Science, 343, 174-178, https://doi.org/10.1126/science.1244341, 2014.

Edwards, T. L., Brandon, M. A., Durand, G., Edwards, N. R., Golledge, N. R., Holden, P. B., Nias, I. J., Payne, A. J., Ritz, C., and Wernecke, A.: Revisiting Antarctic ice loss due to marine ice-cliff instability, Nature, 566, 58, https://doi.org/10.1038/s41586-019-0901-4, 2019.

Favier, L., Durand, G., Cornford, S., Gudmundsson, G., Gagliardini, O., Gillet-Chaulet, F., Zwinger, T., Payne, A., and Le Brocq, A.: Retreat of Pine Island Glacier controlled by marine ice-sheet instability, Nat. Clim. Change, 4, 117-121, https://doi.org/10.1038/nclimate2094, 2014.

Favier, V., Agosta, C., Parouty, S., Durand, G., Delaygue, G., Gallée, H., Drouet, A.-S., Trouvilliez, A., and Krinner, G.: An updated and quality controlled surface mass balance dataset for Antarctica, The Cryosphere, 7, 583-597, https://doi.org/10.5194/tc-7-583-2013, 2013.

Favier, V., Krinner, G., Amory, C., Gallée, H., Beaumet, J., and Agosta, C.: Antarctica-Regional Climate and Surface Mass Budget, Curr. Clim. Change Reports, 3, 303-315, https://doi.org/10.1007/s40641-017-0072-z, 2017.

Fettweis, X., Box, J. E., Agosta, C., Amory, C., Kittel, C., Lang, C., van As, D., Machguth, H., and Gallée, H.: Reconstructions of the 1900-2015 Greenland ice sheet surface mass balance using the regional climate MAR model, The Cryosphere, 11, 1015-1033, https://doi.org/10.5194/tc-11-1015-2017, 2017.

Fogt, R. L. and Wovrosh, A. J.: The Relative Influence of Tropical Sea Surface Temperatures and Radiative Forcing on the Amundsen Sea Low, J. Climate, 28, 8540-8555, https://doi.org/10.1175/jcli-d-15-0091.1, 2015.

Fogt, R. L., Bromwich, D. H., and Hines, K. M.: Understanding the SAM influence on the South Pacific ENSO teleconnection, Clim. Dynam., 36, 1555-1576, https://doi.org/10.1007/s00382010-0905-0, 2011.

Fretwell, P., Pritchard, H. D., Vaughan, D. G., Bamber, J. L., Barrand, N. E., Bell, R., Bianchi, C., Bingham, R. G., Blankenship, D. D., Casassa, G., Catania, G., Callens, D., Conway, H., Cook, A. J., Corr, H. F. J., Damaske, D., Damm, V., Ferraccioli, F., Forsberg, R., Fujita, S., Gim, Y., Gogineni, P., Griggs, J. A., Hindmarsh, R. C. A., Holmlund, P., Holt, J. W., Jacobel, R. W., Jenkins, A., Jokat, W., Jordan, T., King, E. C., Kohler, J., Krabill, W., Riger-Kusk, M., Langley, K. A., Leitchenkov, G., Leuschen, C., Luyendyk, B. P., Matsuoka, K., Mouginot, J., Nitsche, F. O., Nogi, Y., Nost, O. A., Popov, S. V., Rignot, E., Rippin, D. M., Rivera, A., Roberts, J., Ross, N., Siegert, M. J., Smith, A. M., Steinhage, D., Studinger, M., Sun, B., Tinto, B. K., Welch, B. C., Wilson, D., Young, D. A., Xiangbin, C., and Zirizzotti, A.: Bedmap2: improved ice bed, surface and thickness datasets for Antarctica, The Cryosphere, 7, 375-393, https://doi.org/10.5194/tc-7-375-2013, 2013.

Fyke, J., Lenaerts, J. T. M., and Wang, H.: Basin-scale heterogeneity in Antarctic precipitation and its impact on surface mass variability, The Cryosphere, 11, 2595-2609, https://doi.org/10.5194/tc11-2595-2017, 2017.

Gallée, H.: Simulation of the mesocyclonic activity in the Ross Sea, Antarctica, Mon. Weather Rev., 123, 2051-2069, https://doi.org/10.1175/15200493(1995)123<2051:sotmai>2.0.co;2, 1995.

Gallée, H. and Gorodetskaya, I. V.: Validation of a limited area model over Dome C, Antarctic Plateau, during winter, Clim. Dynam., 34, 61, https://doi.org/10.1007/s00382-008-0499-y, 2010.

Gallée, H. and Schayes, G.: Development of a three-dimensional meso- $\gamma$ primitive equation model: katabatic winds simulation in the area of Terra Nova Bay, Antarctica, Mon. Weather Rev., 122, 671-685, https://doi.org/10.1175/15200493(1994)122<0671:doatdm>2.0.co;2, 1994.

Gallée, H., Preunkert, S., Argentini, S., Frey, M. M., Genthon, C., Jourdain, B., Pietroni, I., Casasanta, G., Barral, H., Vignon, E., Amory, C., and Legrand, M.: Characterization of the boundary layer at Dome C (East Antarctica) during the OPALE summer campaign, Atmos. Chem. Phys., 15, 62256236, https://doi.org/10.5194/acp-15-6225-2015, 2015.

Genthon, C. and Cosme, E.: Intermittent signature of ENSO in west-Antarctic precipitation, Geophys. Res. Lett., 30, 2081, https://doi.org/10.1029/2003g1018280, 2003.

Gerber, E. P. and Martineau, P.: Quantifying the variability of the annular modes: reanalysis uncertainty vs. sampling uncertainty, Atmos. Chem. Phys., 18, 17099-17117, https://doi.org/10.5194/acp-18-17099-2018, 2018.

Harangozo, S. A.: The relationship of Pacific deep tropical convection to the winter and springtime extratropical atmospheric circulation of the South Pacific in El Niño events, Geophys. Res. Lett., 31, L05206, https://doi.org/10.1029/2003GL018667, 2004.

Hartmann, D. L. and Lo, F.: Wave-driven zonal flow vacillation in the Southern Hemisphere, J. Atmos. Sci., 55, 1303-1315, https://doi.org/10.1175/15200469(1998)055<1303:wdzfvi>2.0.co;2, 1998.

Holland, P. R., Bracegirdle, T. J., Dutrieux, P., Jenkins, A., and Steig, E. J.: West Antarctic ice loss influenced by internal climate variability and anthropogenic forcing, Nat. Geosci., 12, 718-724, https://doi.org/10.1038/s41561-019-0420-9, 2019.

Hosking, J. S., Orr, A., Marshall, G. J., Turner, J., and Phillips, T.: The influence of the Amundsen-Bellingshausen Seas low on the climate of West Antarctica and its representation in coupled climate model simulations, J. Climate, 26, 6633-6648, https://doi.org/10.1175/jcli-d-12-00813.1, 2013.

Hosking, J. S., Orr, A., Bracegirdle, T. J., and Turner, J.: Future circulation changes off West Antarctica: Sensitivity of the Amundsen Sea Low to projected anthropogenic forcing, Geophys. Res. Lett., 43, 367-376, https://doi.org/10.1002/2015g1067143, 2016.

Hoskins, B. J. and Karoly, D. J.: The steady linear response of a spherical atmosphere to thermal and orographic forcing, J. Atmos. Sci., 38, 1179-1196, https://doi.org/10.1175/15200469(1981)038<1179:tslroa>2.0.co;2, 1981.

Huai, B., Wang, Y., Ding, M., Zhang, J., and Dong, X.: An assessment of recent global atmospheric reanalyses for Antarc- 
tic near surface air temperature, Atmos. Res., 226, 181-191, https://doi.org/10.1016/j.atmosres.2019.04.029, 2019.

Izumo, T., Vialard, J., Lengaigne, M., de Boyer Montegut, C., Behera, S. K., Luo, J.-J., Cravatte, S., Masson, S., and Yamagata, T.: Influence of the state of the Indian Ocean Dipole on the following year's El Niño, Nat. Geosci., 3, 168, https://doi.org/10.1038/ngeo760, 2010.

Jenkins, A., Dutrieux, P., Jacobs, S., Steig, E. J., Gudmundsson, G. H., Smith, J., and Heywood, K. J.: Decadal Ocean Forcing and Antarctic Ice Sheet Response: Lessons from the Amundsen Sea, Oceanography, 29, 106-117, 2016.

Jenkins, A., Shoosmith, D., Dutrieux, P., Jacobs, S., Kim, T. W., Lee, S. H., Ha, H. K., and Stammerjohn, S.: West Antarctic Ice Sheet retreat in the Amundsen Sea driven by decadal oceanic variability, Nat. Geosci., 11, 733-738, https://doi.org/10.1038/s41561-018-0207-4, 2018.

Jones, J. M., Gille, S. T., Goosse, H., Abram, N. J., Canziani, P. O., Charman, D. J., Clem, K. R., Crosta, X., de Lavergne, C., Eisenman, I., England, M. H., Fogt, R. L., Frankcombe, L. M., Marshall, G. J., Masson-Delmotte, V., Morrison, A. K., Orsi, A. J., Raphael, M. N., Renwick, J. A., Schneider, D. P., Simpkins, G. R., Steig, E. J., Stenni, B., Swingedouw, D., and Vance, T. R.: Assessing recent trends in high-latitude Southern Hemisphere surface climate, Nat. Clim. Change, 6, 917-926, https://doi.org/10.1038/nclimate3103, 2016.

Joughin, I., Smith, B. E., and Medley, B.: Marine ice sheet collapse potentially under way for the Thwaites Glacier Basin, West Antarctica, Science, 344, 735-738, https://doi.org/10.1126/science.1249055, 2014.

Jourdain, N. C., Mathiot, P., Merino, N., Durand, G., Le Sommer, J., Spence, P., Dutrieux, P., and Madec, G.: Ocean circulation and sea-ice thinning induced by melting ice shelves in the Amundsen Sea, J. Geophys. Res.-Oceans, 122, 2550-2573, https://doi.org/10.1002/2016jc012509, 2017.

Kingslake, J., Ely, J. C., Das, I., and Bell, R. E.: Widespread movement of meltwater onto and across Antarctic ice shelves, Nature, 544, 349, https://doi.org/10.1038/nature22049, 2017.

Kittel, C., Amory, C., Agosta, C., Delhasse, A., Doutreloup, S., Huot, P.-V., Wyard, C., Fichefet, T., and Fettweis, X.: Sensitivity of the current Antarctic surface mass balance to sea surface conditions using MAR, The Cryosphere, 12, 3827-3839, https://doi.org/10.5194/tc-12-3827-2018, 2018.

Krinner, G., Guicherd, B., Ox, K., Genthon, C., and Magand, O.: Influence of Oceanic Boundary Conditions in Simulations of Antarctic Climate and Surface Mass Balance Change during the Coming Century, J. Climate, 21, 938-962, https://doi.org/10.1175/2007jcli1690.1, 2008.

Kuipers Munneke, P., Ligtenberg, S. R. M., Van Den Broeke, M. R., and Vaughan, D. G.: Firn air depletion as a precursor of Antarctic ice-shelf collapse, J. Glaciol., 60, 205-214, https://doi.org/10.3189/2014JoG13J183, 2014.

Lachlan-Cope, T. and Connolley, W.: Teleconnections between the tropical Pacific and the Amundsen-Bellinghausens Sea: Role of the El Niño/Southern Oscillation, J. Geophys. Res.-Atmos., 111, D23101, https://doi.org/10.1029/2005JD006386, 2006.

Lang, C., Fettweis, X., and Erpicum, M.: Future climate and surface mass balance of Svalbard glaciers in an RCP8.5 climate scenario: a study with the regional climate model
MAR forced by MIROC5, The Cryosphere, 9, 945-956, https://doi.org/10.5194/tc-9-945-2015, 2015.

Lenaerts, J., den Broeke, M., Déry, S., Meijgaard, E., Berg, W., Palm, S. P., and Sanz Rodrigo, J.: Modeling drifting snow in Antarctica with a regional climate model: 1. Methods and model evaluation, J. Geophys. Res.-Atmos., 117, D05108, https://doi.org/10.1029/2011jd016145, 2012.

Lenaerts, J. T., Vizcaino, M., Fyke, J., Van Kampenhout, L., and van den Broeke, M. R.: Present-day and future Antarctic ice sheet climate and surface mass balance in the Community Earth System Model, Clim. Dynam., 47, 1367-1381, https://doi.org/10.1007/s00382-015-2907-4, 2016.

Lenaerts, J. T., Ligtenberg, S. R., Medley, B., Van de Berg, W. J., Konrad, H., Nicolas, J. P., Van Wessem, J. M., Trusel, L. D., Mulvaney, R., Tuckwell, R. J., Hogg, A. E., and Thomas, E. R.: Climate and surface mass balance of coastal West Antarctica resolved by regional climate modelling, Ann. Glaciol., 59, 29-41, https://doi.org/10.1017/aog.2017.42, 2017.

Ligtenberg, S., Van de Berg, W., Van den Broeke, M., Rae, J., and Van Meijgaard, E.: Future surface mass balance of the Antarctic ice sheet and its influence on sea level change, simulated by a regional atmospheric climate model, Clim. Dynam., 41, 867-884, https://doi.org/10.1007/s00382-013-1749-1, 2013.

Limpasuvan, V. and Hartmann, D. L.: Eddies and the annular modes of climate variability, Geophys. Res. Lett., 26, 31333136, https://doi.org/10.1029/1999gl010478, 1999.

Marshall, G. J.: Trends in the Southern Annular Mode from observations and reanalyses, J. Climate, 16, 4134-4143, https://doi.org/10.1175/1520 0442(2003)016<4134:titsam>2.0.co;2 2003.

Medley, B. and Thomas, E.: Increased snowfall over the Antarctic Ice Sheet mitigated twentieth-century sea-level rise, Nat. Clim. Change, 9, 34, https://doi.org/10.1038/s41558-018-0356$\mathrm{x}, 2019$.

Medley, B., Joughin, I., Das, S., Steig, E., Conway, H., Gogineni, S., Criscitiello, A., McConnell, J., Smith, B., van den Broeke, M., Lenaerts, J. T. M., Bromwich, D. H., and Nicolas, J. P.: Airborne-radar and ice-core observations of annual snow accumulation over Thwaites Glacier, West Antarctica confirm the spatiotemporal variability of global and regional atmospheric models, Geophys. Res. Lett., 40, 3649-3654, https://doi.org/10.1002/grl.50706, 2013.

Medley, B., Joughin, I., Smith, B. E., Das, S. B., Steig, E. J., Conway, H., Gogineni, S., Lewis, C., Criscitiello, A. S., McConnell, J. R., van den Broeke, M. R., Lenaerts, J. T. M., Bromwich, D. H., Nicolas, J. P., and Leuschen, C.: Constraining the recent mass balance of Pine Island and Thwaites glaciers, West Antarctica, with airborne observations of snow accumulation, The Cryosphere, 8, 1375-1392, https://doi.org/10.5194/tc8-1375-2014, 2014.

Merino, N., Jourdain, N. C., Le Sommer, J., Goosse, H., Mathiot, P., and Durand, G.: Impact of increasing antarctic glacial freshwater release on regional sea-ice cover in the Southern Ocean, Ocean Modell., 121, 76-89, https://doi.org/10.1016/j.ocemod.2017.11.009, 2018.

Mo, K. C. and Higgins, R. W.: The Pacific-South American Modes and Tropical Convection during the Southern Hemisphere Winter, Mon. Weather 
Rev., 126, 1581-1596, https://doi.org/10.1175/15200493(1998)126<1581:TPSAMA>2.0.CO;2, 1998.

Mouginot, J., Rignot, E., and Scheuchl, B.: Sustained increase in ice discharge from the Amundsen Sea Embayment, West Antarctica, from 1973 to 2013, Geophys. Res. Lett., 41, 1576-1584, https://doi.org/10.1002/2013g1059069, 2014.

Newman, M., Shin, S.-I., and Alexander, M. A.: Natural variation in ENSO flavors, Geophys. Res. Lett., 38, L14705, https://doi.org/10.1029/2011g1047658, 2011.

Nicolas, J. P. and Bromwich, D. H.: Climate of West Antarctica and Influence of Marine Air Intrusions, J. Climate, 24, 49-67, https://doi.org/10.1175/2010JCLI3522.1, 2010.

Nicolas, J. P., Vogelmann, A. M., Scott, R. C., Wilson, A. B., Cadeddu, M. P., Bromwich, D. H., Verlinde, J., Lubin, D., Russell, L. M., Jenkinson, C., Powers, H. H., Ryczek, M., Stone, G., and Wille, J. D.: January 2016 extensive summer melt in West Antarctica favoured by strong El Niño, Nat. Commun., 8, ncomms15799, https://doi.org/10.1038/ncomms15799, 2017.

Palerme, C., Genthon, C., Claud, C., Kay, J. E., Wood, N. B., and L'Ecuyer, T.: Evaluation of current and projected Antarctic precipitation in CMIP5 models, Clim. Dynam., 48, 225-239, https://doi.org/10.1007/s00382-016-3071-1, 2017.

Paolo, F., Padman, L., Fricker, H., Adusumilli, S., Howard, S., and Siegfried, M.: Response of Pacific-sector Antarctic ice shelves to the El Niño/Southern Oscillation, Nat. Geosci., 11, 121-126, https://doi.org/10.1038/s41561-017-0033-0, 2018.

Pattyn, F., Ritz, C., Hanna, E., Asay-Davis, X., DeConto, R., Durand, G., Favier, L., Fettweis, X., Goelzer, H., Golledge, N. R., Kuipers Munneke, P., Lenaerts, J. T. M., Nowicki, S., Payne, A. J., Robinson, A., Seroussi, H., Trusel, L. D., and van den Broeke, M.: The Greenland and Antarctic ice sheets under $1.5^{\circ} \mathrm{C}$ global warming, Nat. Clim. Change, 8, 1053-1061, https://doi.org/10.1038/s41558-018-0305-8, 2018.

Peters, D. H. and Vargin, P.: Influence of subtropical Rossby wave trains on planetary wave activity over Antarctica in September 2002, Tellus A, 67, 25875, https://doi.org/10.3402/tellusa.v67.25875, 2015.

Pfeffer, W. T., Meier, M. F., and Illangasekare, T. H.: Retention of Greenland runoff by refreezing: Implications for projected future sea level change, J. Geophys. Res.-Oceans, 96, 22117-22124, https://doi.org/10.1029/91JC02502, 1991.

Philander, S., Lau, N., Pacanowski, R., and Nath, M.: Two Different Simulations of the Southern Oscillation and El Nino with Coupled Ocean-Atmosphere General Circulation Models, Philos. Trans. Roy. Soc. London A, 329, 167-177, https://doi.org/10.1098/rsta.1989.0068, 1989.

Picard, G. and Fily, M.: Surface melting observations in Antarctica by microwave radiometers: Correcting 26-year time series from changes in acquisition hours, Remote Sens. Environ., 104, 325336, https://doi.org/10.1016/j.rse.2006.05.010, 2006.

Picard, G., Fily, M., and Gallée, H.: Surface melting derived from microwave radiometers: a climatic indicator in Antarctica, Ann. Glaciol., 46, 29-34, https://doi.org/10.3189/172756407782871684, 2007.

Pope, J. O., Holland, P. R., Orr, A., Marshall, G. J., and Phillips, T.: The impacts of El Niño on the observed sea ice budget of West Antarctica, Geophys. Res. Lett., 44, 6200-6208, https://doi.org/10.1002/2017GL073414, 2017.
Pritchard, H., Ligtenberg, S., Fricker, H., Vaughan, D., Van den Broeke, M., and Padman, L.: Antarctic ice-sheet loss driven by basal melting of ice shelves, Nature, 484, 502-505, https://doi.org/10.1038/nature10968, 2012.

Raphael, M., Marshall, G., Turner, J., Fogt, R., Schneider, D., Dixon, D., Hosking, J., Jones, J., and Hobbs, W.: The Amundsen Sea low: Variability, change, and impact on Antarctic climate, B. Am. Meteorol. Soc., 97, 111-121, https://doi.org/10.1175/bamsd-14-00018.1, 2016.

Raphael, M. N. and Hobbs, W.: The influence of the large-scale atmospheric circulation on Antarctic sea ice during ice advance and retreat seasons, Geophys. Res. Lett., 41, 5037-5045, https://doi.org/10.1002/2014g1060365, 2014.

Rignot, E., Mouginot, J., Scheuchl, B., van den Broeke, M., van Wessem, M. J., and Morlighem, M.: Four decades of Antarctic Ice Sheet mass balance from 1979-2017, P. Natl. Acad. Sci. USA, 116, 1095-1103, https://doi.org/10.1073/pnas.1812883116, 2019.

Ritz, C., Edwards, T. L., Durand, G., Payne, A. J., Peyaud, V., and Hindmarsh, R. C.: Potential sea-level rise from Antarctic icesheet instability constrained by observations, Nature, 528, 115118, https://doi.org/10.1038/nature16147, 2015.

Ropelewski, C. F. and Jones, P. D.: An Extension of the Tahiti-Darwin Southern Oscillation Index, Mon. Weather Rev., 115, 2161-2165, https://doi.org/10.1175/15200493(1987)115<2161:AEOTTS>2.0.CO;2, 1987.

Roundy, P. E.: On the Interpretation of EOF Analysis of ENSO, Atmospheric Kelvin Waves, and the MJO, J. Climate, 28, 11481165, https://doi.org/10.1175/JCLI-D-14-00398.1, 2014.

Scambos, T., Fricker, H. A., Liu, C.-C., Bohlander, J., Fastook, J., Sargent, A., Massom, R., and Wu, A.-M.: Ice shelf disintegration by plate bending and hydro-fracture: Satellite observations and model results of the 2008 Wilkins ice shelf break-ups, Earth Planet. Sci. Lett., 280, 51-60, https://doi.org/10.1016/j.epsl.2008.12.027, 2009.

Schoof, C.: Ice sheet grounding line dynamics: Steady states, stability, and hysteresis, J. Geophys. Res.-Earth Surf., 112, F03S28, https://doi.org/10.1029/2006jf000664, 2007.

Scott, R. C., Nicolas, J. P., Bromwich, D. H., Norris, J. R., and Lubin, D.: Meteorological Drivers and Large-Scale Climate Forcing of West Antarctic Surface Melt, J. Climate, 32, 665-684, https://doi.org/10.1175/jcli-d-18-0233.1, 2019.

Scott Yiu, Y. Y. and Maycock, A. C.: On the Seasonality of the El Niño Teleconnection to the Amundsen Sea Region, J. Climate, 32, 4829-4845, https://doi.org/10.1175/JCLI-D-180813.1, 2019.

Shepherd, A. and Nowicki, S.: Improvements in ice-sheet sea-level projections, Nat. Clim. Change, 7, 672-674, https://doi.org/10.1038/nclimate3400, 2017.

Shepherd, A., Ivins, E., Rignot, E., et al.: Mass balance of the Antarctic ice sheet from 1992 to 2017, Nature, 558, 219-222, https://doi.org/10.1038/s41586-018-0179-y, 2018.

Steig, E. J., Schneider, D. P., Rutherford, S. D., Mann, M. E., Comiso, J. C., and Shindell, D. T.: Warming of the Antarctic icesheet surface since the 1957 International Geophysical Year, Nature, 457, 459-462, https://doi.org/10.1038/nature07669, 2009.

Steig, E. J., Ding, Q., Battisti, D., and Jenkins, A.: Tropical forcing of Circumpolar Deep Water inflow and outlet glacier thinning in 
the Amundsen Sea Embayment, West Antarctica, Ann. Glaciol., 53, 19-28, https://doi.org/10.3189/2012aog60a110, 2012.

Tedesco, M.: Assessment and development of snowmelt retrieval algorithms over Antarctica from K-band spaceborne brightness temperature (1979-2008), Remote Sens. Environ., 113, 979997, https://doi.org/10.1016/j.rse.2009.01.009, 2009.

Thoma, M., Jenkins, A., Holland, D., and Jacobs, S.: Modelling circumpolar deep water intrusions on the Amundsen Sea continental shelf, Antarctica, Geophys. Res. Lett., 35, L18602, https://doi.org/10.1029/2008g1034939, 2008.

Thomas, E. R., Hosking, J. S., Tuckwell, R. R., Warren, R. A., and Ludlow, E. C.: Twentieth century increase in snowfall in coastal West Antarctica, Geophys. Res. Lett., 42, 9387-9393, https://doi.org/10.1002/2015GL065750, 2015.

Thompson, D. W. and Wallace, J. M.: Annular modes in the extratropical circulation, Part I: month-to-month variability*, J. Climate, 13, 1000-1016, https://doi.org/10.1175/15200442(2000)013<1000:amitec >2.0.co;2, 2000.

Torinesi, O., Fily, M., and Genthon, C.: Variability and trends of the summer melt period of Antarctic ice margins since 1980 from microwave sensors, J. Climate, 16, 1047-1060, https://doi.org/10.1175/15200442(2003)016<1047:vatots>2.0.co;2, 2003.

Trusel, L. D., Frey, K. E., and Das, S. B.: Antarctic surface melting dynamics: Enhanced perspectives from radar scatterometer data, J. Geophys. Res.-Earth Surf., 117, F02023, https://doi.org/10.1029/2011JF002126, 2012.

Trusel, L. D., Frey, K. E., Das, S. B., Munneke, P. K., and Broeke, M. R.: Satellite-based estimates of Antarctic surface meltwater fluxes, Geophys. Res. Lett., 40, 6148-6153, https://doi.org/10.1002/2013gl058138, 2013.

Trusel, L. D., Frey, K. E., Das, S. B., Karnauskas, K. B., Munneke, P. K., Van Meijgaard, E., and Van Den Broeke, M. R.: Divergent trajectories of Antarctic surface melt under two twenty-first-century climate scenarios, Nat. Geosci., 8, 927, https://doi.org/10.1038/ngeo2563, 2015.

Turner, J., Comiso, J. C., Marshall, G. J., Lachlan-Cope, T. A., Bracegirdle, T., Maksym, T., Meredith, M. P., Wang, Z., and Orr, A.: Non-annular atmospheric circulation change induced by stratospheric ozone depletion and its role in the recent increase of Antarctic sea ice extent, Geophys. Res. Lett., 36, L08502, https://doi.org/10.1029/2009g1037524, 2009.
Turner, J., Phillips, T., Hosking, J. S., Marshall, G. J., and Orr, A.: The Amundsen Sea low, Int. J. Climatol., 33, 1818-1829, https://doi.org/10.1002/joc.3558, 2013a.

Turner, J., Hosking, J. S., Phillips, T., and Marshall, G. J.: Temporal and spatial evolution of the Antarctic sea ice prior to the September 2012 record maximum extent, Geophys. Res. Lett., 40, 5894-5898, https://doi.org/10.1002/2013GL058371, 2013 b.

Turner, J., Orr, A., Gudmundsson, G. H., Jenkins, A., Bingham, R. G., Hillenbrand, C.-D., and Bracegirdle, T. J.: Atmosphere-Ocean-Ice Interactions in the Amundsen Sea Embayment, West Antarctica, Rev. Geophys., 55, 235-276, https://doi.org/10.1002/2016rg000532 2017.

Van den Broeke, M.: Strong surface melting preceded collapse of Antarctic Peninsula ice shelf: Melting on Antarctic ice shelves, Geophys. Res. Lett., 32, L12815, https://doi.org/10.1029/2005GL023247, 2005.

Vaughan, D. G., Marshall, G. J., Connolley, W. M., Parkinson, C., Mulvaney, R., Hodgson, D. A., King, J. C., Pudsey, C. J., and Turner, J.: Recent Rapid Regional Climate Warming on the Antarctic Peninsula, Clim. Change, 60, 243-274, https://doi.org/10.1023/A:1026021217991, 2003.

Wang, Y., Ding, M., van Wessem, J. M., Schlosser, E., Altnau, S., van den Broeke, M. R., Lenaerts, J. T. M., Thomas, E. R., Isaksson, E., Wang, J., and Sun, W.: A Comparison of Antarctic Ice Sheet Surface Mass Balance from Atmospheric Climate Models and In Situ Observations, J. Climate, 29, 5317-5337, https://doi.org/10.1175/JCLI-D-15-0642.1, 2016.

Weertman, J.: Stability of the junction of an ice sheet and an ice shelf, J. Glaciol., 13, 3-11, https://doi.org/10.3189/s0022143000023327, 1974.

Yuan, X. and Martinson, D. G.: The Antarctic dipole and its predictability, Geophys. Res. Lett., 28, 3609-3612, https://doi.org/10.1029/2001gl012969, 2001. 